\title{
Influence of granitoid textural parameters on sediment composition: Implications for sediment generation
}

\author{
L. Caracciolo a,*, R. Tolosana-Delgado ${ }^{\text {b }}$, E. Le Pera ${ }^{\text {a }}$, H. von Eynatten ${ }^{\text {c }}$, J. Arribas ${ }^{\text {d }}$, S. Tarquini ${ }^{\text {e }}$ \\ a Dipartimento di Scienze della Terra, Università della Calabria, via P. Bucci, cubo 15b, 87036, Rende (CS), Italy \\ b Dept. d'Enginyeria Hidràulica i Ambiental, Laboratori d'Enginyeria Maritima (LIM/UPC) Universitat politecnica de Catalunya, Barcelona, Spain \\ c Geowissenschaftliches Zentrum der Georg-August-Universität Göttingen, Abteilung Sedimentologie/Umweltgeologie, Goldschmidtstrasse 3, D-37077 Göttingen, Germany \\ ' Dpto. de Petrología y Geoquímica, Univ. Complutense de Madrid-CSIC, C/Jose Antonio Novais 2, 28040 Madrid, Spain \\ e Istituto Nazionale di Geofisica e Vulcanologia, Sezione di Pisa, Via della Faggiola, 32, 56126 Pisa, Italy
}

\section{A R T I C L E I N F O}

\section{Article history:}

Received 18 July 2011

Received in revised form 2 July 2012

Accepted 9 July 2012

Available online 20 July 2012

\section{Keywords:}

Textural parameters

Grain size

Mineral interfaces

Composition

Glacial environment

Sediment generation

\begin{abstract}
A B S T R A C T
The aim of this study is to determine and characterise the control exerted by parent rock texture on sand composition as a function of grain size. The sands investigated were generated from granitoid parent rocks by the Rhone, Damma and Sidelen glaciers, which drain the Aar Massif in the Central Alps (Switzerland), and were deposited in glacial and fluvio-glacial settings. Mechanical erosion, comminution (crystal breakdown and abrasion) and hydraulic sorting are the most important processes controlling the generation of sediments in this environment, whereas chemical and/or biochemical weathering plays a negligible role. By using a GIS-based Microscopic Information System (MIS), five samples from the glacier-drained portions of the Aar basement have been analysed to determine textural parameters such as modal composition, crystal size distribution and mineral interfaces (types and lengths). Petrographic data of analysed sands include traditional point counts (Gazzi-Dickinson method, minimum of 300 points) as well as textural counts to determine interface types, frequency, and polycrystallinity in phaneritic rock fragments. According to Pettijohn's classification, grain-size dependent compositions vary from feldspathic litharenite ( $0 \varphi$ fraction) via lithic arkose $(1 \varphi$ and $2 \varphi$ ) to arkose $(3 \varphi$ and $4 \varphi$ ). Compositional differences among our data set were compared to modern plutoniclastic sands from the Iberian Massif (Spain) and the St. Gabriel Mts. (California, USA), which allowed us to assess the role exerted by glaciers in generating sediments. By combining data from the MIS with those from petrographic analysis, we outlined the evolution of mineral interfaces from the parent rocks to the sediments.
\end{abstract}

(C) 2012 Elsevier B.V. All rights reserved.

\section{Introduction}

Sandstone composition has long been used as a tool to infer the tectonic setting of ancient sediment source regions (e.g., Dickinson, 1970, 1985; Dickinson and Suczek, 1979). Studies of modern continental and marine sands can elucidate the relative importance of processes controlling the composition of generated sediments, particularly of sands, in the geologic record. An advantage of studying modern sand is that lithology, physiography and climate of provenance areas can be unambiguously identified (Valloni, 1985; Ibbeken and Schleyer, 1991; Johnsson et al., 1991). Many studies, based on sand(stone) petrology, have been directed at evaluating controls such as provenance (Suttner, 1974), transportation (Osborne et al., 1993), depositional environment (Davies and Ethridge, 1975; Kairo et al., 1993), diagenesis (Scholle and Schluger, 1979; McDonald and Surdam, 1984), and sampling scale (Ingersoll, 1990; Weltje, 2004), all of which are known to profoundly affect sand(stone) composition (Johnsson, 1993; Basu, 2003; Weltje

\footnotetext{
* Corresponding author.

E-mail address: luca.caracciolo@unical.it (L. Caracciolo).
}

and von Eynatten, 2004). Furthermore, numerous studies have demonstrated a strong dependence of sand(stone) composition on grain size (e.g. Whitmore et al., 2004; Garzanti et al., 2009). Heins (1993, 1995) provided a wealth of information on framework composition of modern felsic plutoniclastic sands derived from granitoid plutons of the Cordilleras of the United States and Mexico. These studies demonstrated that the textural parameters of parent rocks represent the main control on rock-fragment abundance in modern plutoniclastic sand (Heins, 1993), and that the types of mineral interfaces preserved in rock fragments are closely related to climate and topography of the source area (Heins, 1995). Palomares and Arribas (1993) introduced the Sand Generation Index (SGI) for granitic and metamorphic terrains in the Spanish Central System as a method for quantifying the capacity of different parent rocks to produce sand-sized detritus.

Plutoniclastic sands consist of a mixture of chemically and mechanically durable grains such as mono- and polycrystalline quartz, and labile grains such as feldspars, rock fragments, and accessories (e.g., Garzanti et al., 1996; Le Pera et al., 2001; Caracciolo et al., 2011). Ratios between these two groups of grains are sensitive to climate conditions (e.g., Todd, 1968; Pittman, 1970; Mack and Suttner, 1977; 
Helmold, 1985; Suttner and Dutta, 1986; van de Kamp et al., 1994; Weltje et al., 1998). The climatic signature is preserved in the sandy detritus if it does not suffer sedimentary differentiation during longdistance transport and deposition in high-energy littoral environments (Suttner et al., 1981) or exceptionally deep burial diagenesis (Suttner and Dutta, 1986). Studies of Holocene sands may provide actualistic compositional data to serve as a basis for inferring paleoclimate from ancient sandstones (e.g., Young et al., 1975; Basu, 1976; James et al., 1981; Franzinelli and Potter, 1983; Grantham and Velbel, 1988; Girty, 1991; Heins, 1993,1995; Weltje et al., 1998; Le Pera et al., 2001).

The purpose of the present study is twofold. The first is to determine the influence exerted by parent rock texture on the generation of sediments by means of grain size-composition trends, based on modal and interface analysis of rock fragments. The second is to characterise the generation and comminution of sediments in glacial settings. Quantified parent rock texture, climate, tectonic setting, depositional environment and topography of source areas are indispensable ingredients for predictive models of sediment generation (Weltje, 2012-this issue).

\subsection{Geological background}

Our study is focused on sediments derived from modern to sub-modern front and side moraines of three retreating glaciers, the Rhone, Damma and Sidelen (Switzerland, Cantons of Valais, Uri and Schwyz) (Fig. 1). These glaciers drain and erode almost pure granitoid lithologies from the so-called central Aar granite (Aar massif, Central Alps), covering a large area (approx. $550 \mathrm{~km}^{2}$ ) of granitoid bodies (Schaltegger, 1990a, 1990b). The mean emplacement age is $298 \pm$ $2 \mathrm{Ma}$ (Schaltegger and Corfu, 1994). The exhumation of the Aar massif is generally attributed to the late Miocene (Michalski and Soom, 1990).

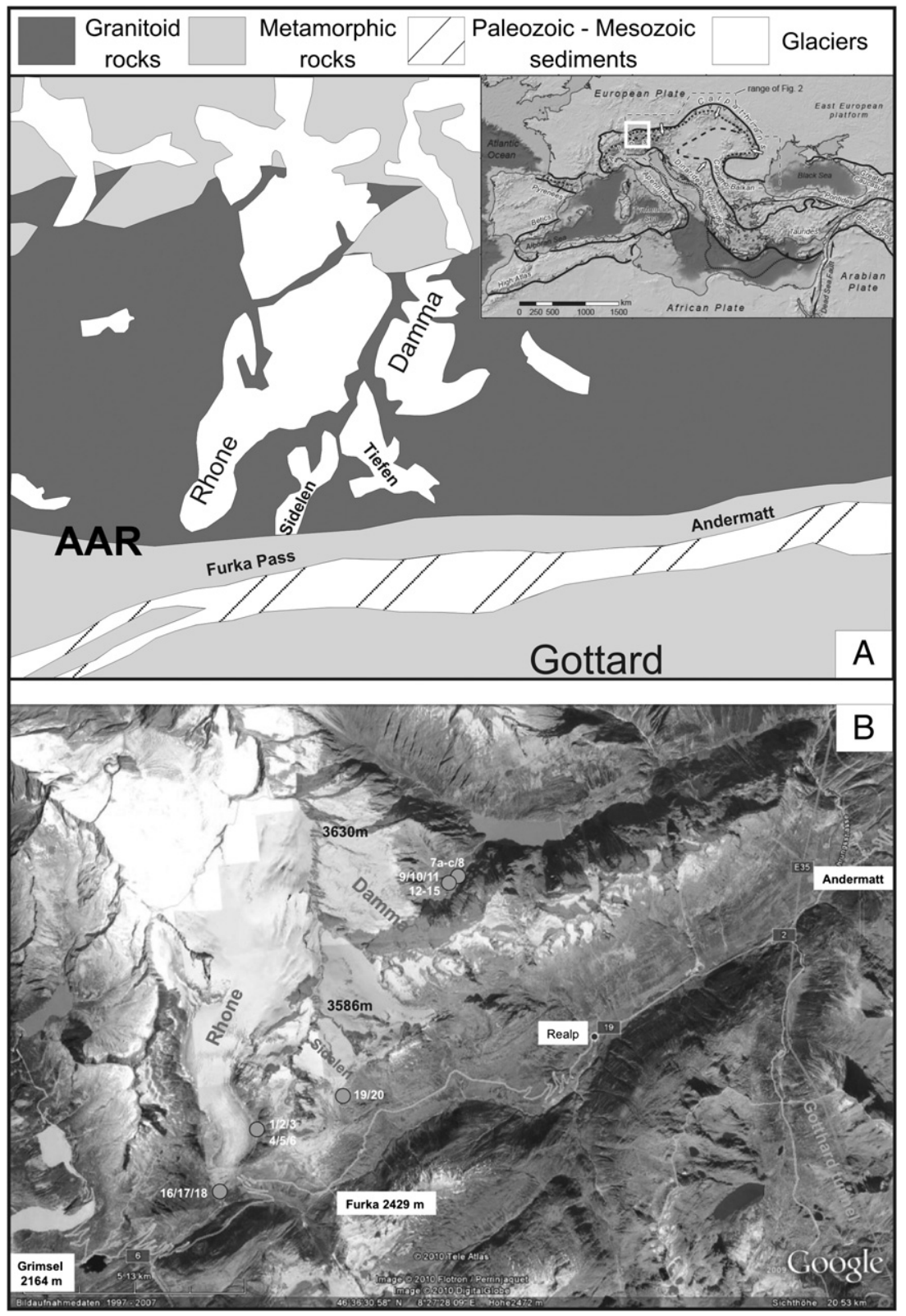

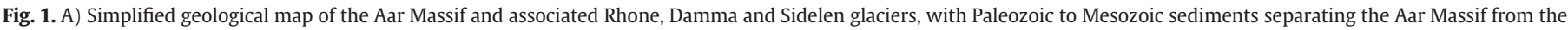

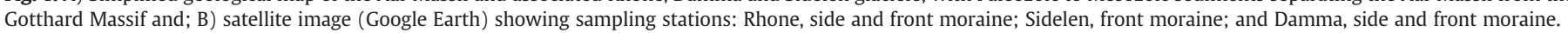
Modified from Labhart (1977). 
According to Debon and Lemmet (1999), the modal composition of the granitoids varies around quartz $28 \pm 7 \%$, feldspar $63 \pm 2 \%$ and mafics $1-14 \%$ (with a ratio feldspar/quartz of 1:1). Monzogranites of the Central Aar granite s.s. exhibit a narrower range (quartz $32 \pm 2 \%$, feldspar $62 \pm 4 \%$, mafics $6 \pm 2 \%$, ratio feldspar/quartz of $2: 1$ ). Characteristic mafic and accessory minerals are biotite, garnet, titanite, allanite (epidote group), and rarely fluorite.

\section{Theoretical basis and rationale}

\subsection{The role of parent rock texture in sediment generation}

Mineral interfaces, or generically crystal boundaries, represent the primary control on the separation of grains from parent rocks, as well as on the durability of lithic fragments (Slatt and Eyles, 1981; Heins, 1995). Few studies concentrated on fracturation processes in sedimentary environments (Moss, 1966; Smalley and Vita-Finzi, 1968; Walker and Hutka, 1971; Riezebos and Van der Waals, 1974; Moss and Green, 1975) and most of them focus on the fracturation of quartz grains. Fractures propagate preferentially along mineral interfaces (Brace, 1964; Slatt and Eyles, 1981; Heins, 1995). The nature of interfaces is strongly dependent on rates of cooling and crystallisation, which determine the degree of internal organisation of rocks (Erkan, 1970; Simmons and Richters, 1976; Heins, 1995). A slower cooling favours a more efficient internal organisation, so that chances to form durable interfacial bonds are drastically reduced. Conversely, a faster cooling will produce crystals with higher densities of unsatisfied bonds on crystal surfaces, creating favourable conditions for attachment to other grains. As a consequence, slow cooling rates produce porphyritic coarse-grained granitoids in which phenocrysts form unstable/less durable interfaces than fast cooling rates which result in fine-grained granitoids.

Durability of mineral interfaces is directly linked to chemical and crystallographic affinities and associated textural relationships. The higher these similarities, the stronger will be the durability of mineral interfaces. From a chemical point of view the most stable mineral interfaces are those characterised by high congruence of structure and type of bonding (Heins, 1995). Isostructural tectosilicate contacts such as QQ-KK-PP (Quartz-K-feldspar-Plagioclase) and mixed tectosilicate interfaces such as $\mathrm{QP}-\mathrm{QK}$ should be more durable than mixed tectosilicate-phyllosilicate interfaces (e.g. Q-M, quartz-micas).

\subsection{Mechanical disaggregation and sediment generation}

Mineral disaggregation and consequent grain-size reduction (comminution) depend on (i) physical mineral properties and (ii) stress fields acting on interface categories (Slatt and Eyles, 1981, and references therein). Most of the parameters which determine the first category are related to the nature of mineral interfaces and rates of crystallisation. Moreover, planes of weakness and subcrystal boundaries (e.g. K-feldspar albitization), as well as cleavage planes in feldspar, are all responsible for incipient microfractures which trigger mineral breakdown (Moss, 1966; McWilliams, 1966; Blatt, 1967; Lidstrom, 1968; Moss and Green, 1975; Lorimer, 1976; White, 1976; Irfan and Dearman, 1978; Baynes and Dearman, 1978; Sprunt and Nur, 1979; Slatt and Eyles, 1981; Heins, 1995). Stress fields depend on a complex web of factors, such as the bedrock (rigid in case of glacial environments and deformable in case of sediment beds) and strain types (shear, tensile etc.). Simple shear produces abrasion (Boulton, 1978) whereas tensile stresses trigger mineral breakdown (McWilliams, 1966; Slatt and Eyles, 1981). Thus, in glacial environments, rock disaggregation may occur during grain collision, when the stress field is concentrated at the point of impact (breakdown), or when sand grains become trapped between gravel clasts (abrasion and grinding) (Harrell and Blatt, 1978).

\section{Methods}

\subsection{Sampling and point-counting method}

Ten sand samples were collected from the side and front portions of the moraines of the Rhone and Damma glaciers and from the front moraine and stream/outwash of the Sidelen glacier (Fig. 1). All samples were weighted and sieved into five grain-size fractions (indicated as $0<\varphi<4$; numbers represent the lower grain size limit, e.g., $0 \varphi$ corresponds to the $-1 \varphi$ to $0 \varphi$ interval) and then impregnated and thin-sectioned for petrographic analysis. Thin sections were etched by $40 \%$ hydrofluoric acid and stained by sodium cobaltinitrite for discrimination of plagioclases and K-feldspars, respectively. At least 300 points were counted in each thin section according to the Gazzi-Dickinson method (Ingersoll et al., 1984; Zuffa, 1985, 1987). In addition to conventional point counts of light/heavy minerals and rock-fragment petrographic classes, separate counts were made to quantify rock-fragment polycrystallinity, (determined by classifying phaneritic polycrystalline rock fragments according to the number of crystals: $2-3,4,5$ and $>5$ crystals), and mineral interfaces. A modified version of the criteria introduced by Heins (1995) has been used for the interface counts. Interface point counting was performed on sand-sized crystals excluding inclusions of accessory minerals. Fine-grained polycrystalline quartz (quartz crystals $<63 \mu$ ), was classified as a single quartz grain on account of its mechanical properties. Sandstone classification schemes of Folk (1968), Dickinson (1970, 1985), and Pettijohn (1975) were used. Texture analysis was carried out on plutonic and metamorphic rocks representative of the Rhone, Damma and Sidelen crystalline basement. Image processing was used to determine modal composition, interface types and crystal-size distribution (CSD) of parent rocks (Higgins, 2006; Tarquini and Favalli, 2010).

\subsection{GIS technology for quantitative rock texture analysis}

Granitoid textural parameters have been obtained by applying a GIS-based approach, the Microscopic Information System (MIS, Tarquini and Favalli, 2010) (Table 1). The method consists of: (i) highresolution acquisition of multiple thin section images under different lighting conditions, e.g. plain polarized light and crossed polarized light (Terribile and Fitzpatrick, 1992; Armienti and Tarquini, 2002; Pirard, 2004); (ii) parallel processing of image layers by regiongrowing algorithms; (iii) conversion of processed images to vector format; (iv) use of GIS vector-based tools for texture refinements aimed at obtaining distinct crystals; ( $v$ ) assignment of crystals to mineral phases (quartz, plagioclase, K-feldspar and femic minerals). Integration of the MIS with topological capabilities of a GIS (using ESRI ArcView 3.2) allowed quantitative characterisation of textural parameters. Textural vector maps were processed to obtain crystal size distributions (CSDs) and the complete layout of contacts among crystals.

Standard GIS tools were used to create a database containing a number of geometric and typological parameters for each crystal (e.g. perimeter, area, and diameter in the first phase, attributes such as mineral phase assignment in the second). The database was used to derive the CSD of each sample using a stereological inversion algorithm (Higgins, 2000, 2006). Crystal-size distributions are expressed as percentage volume as a function of crystal diameter (D), using linear binning per given size class. This tool provides the cumulative length and the cumulative number of contacts among crystals, linking all possible combinations of mineral phases (quartz, plagioclase, K-feldspar, and femic minerals).

\subsection{Statistical methods}

\subsubsection{Compositional data analysis}

Most of the information obtained from the analysed samples is compositional in nature: petrographic composition, chemical composition 
Table 1

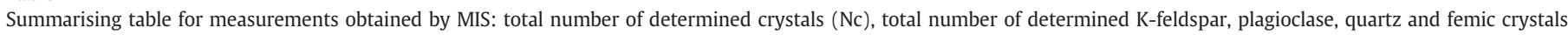

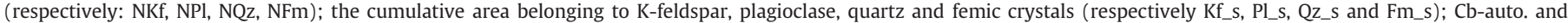
$\mathrm{Cb}$-hand. are cumulative length of the automatically and manually derived crystal boundary; \%Undet is the percent of undetermined area inside the ROI.

\begin{tabular}{|c|c|c|c|c|c|c|c|}
\hline Section Id & RT1-04 & RT1-05 & RT1-12 & RT1-13 & RT 1-14 & Sum & \\
\hline $\mathrm{Nc}$ & 2344 & 1550 & 4861 & 1526 & 2131 & 12,412 & \\
\hline NKf & 888 & 381 & 1635 & 323 & 413 & 3640 & \\
\hline $\mathrm{NPI}$ & 535 & 496 & 1148 & 617 & 1133 & 3929 & \\
\hline NQz & 795 & 535 & 2029 & 401 & 281 & 4041 & \\
\hline NFm & 126 & 138 & 49 & 185 & 304 & 802 & \\
\hline Kf_s & 269.9 & 357.7 & 235.6 & 231.4 & 158.4 & 1252.9 & \\
\hline Pl_S & 158.0 & 147.0 & 149.0 & 242.4 & 302.1 & 998.5 & \\
\hline Qz_S & 208.8 & 129.2 & 213.5 & 133.4 & 144.7 & 829.6 & \\
\hline Fm_s & 18.3 & 23.7 & 6.6 & 35.5 & 49.2 & 133.3 & Average \\
\hline $\mathrm{Cb}(\mathrm{mm})$ & 6675.4 & 4912.5 & 8103.5 & 5292.2 & 6451.3 & $31,434.9$ & 6287.0 \\
\hline Cb-hand mm/sect & 4.1 & 11.0 & 3.8 & 19.1 & 3.9 & & 6.9 \\
\hline \%Undetermined & 3.2 & 3.3 & 5.2 & 2.4 & 2.8 & & 3.1 \\
\hline
\end{tabular}

(von Eynatten et al., 2012-this issue), interface abundances, and numbers of polycrystalline grains. Compositional variables are positive, and each expresses the relative importance of a component in each sample. Statistical analysis of compositional data has been long recognised as potentially problematic, due to the spurious correlation induced by closure to a constant sum of $100 \%$ (Chayes, 1960). For this reason, all statistical tools in this paper are based on the log-ratio approach of Aitchison (1986), the safest way to avoid misinterpretation of spurious correlations (Tolosana-Delgado, 2012). This approach is based on the realisation that the only information conveyed by a compositional data set is relative, and should be expressed in terms of log-ratios. Log-ratio transformed data are unconstrained and can be treated with standard statistical tools. Three compatible families of log-ratio transformations are used in this paper:

- Additive log-ratio transformations, where a D-part composition $\mathbf{x}$ yields $D(D-1)$ different log-ratios of all possible pairs of components; these can be represented in matrices of plots;

- Centred log-ratio transformation (Aitchison, 1982), where a composition $\mathbf{x}$ is transformed to $\mathbf{y}=\operatorname{clr}(\mathbf{x})=\ln (\mathbf{x} / g(\mathbf{x}))$, with the logarithm applied component-wise, in which $g(\mathbf{x})$ is the geometric average of $\mathbf{x}$. The clr relates each original variable to a transformed one (useful for graphical representation) and is invertible: we can recover the original composition as the closure of $\exp (\mathbf{y})$ to constant sum $100 \%$;

- Log-ratio balances (Egozcue and Pawlowsky-Glahn, 2006) between two groups of components are the log-ratios of the respective geometric means of each group. Both of the options given above may be regarded as balances: each additive log-ratio is a balance of two one-component groups, and each clr transformed score is a balance of one component against all the other.

\subsubsection{Descriptive diagrams}

To explore the structure of a compositional data set, we have used the so-called (covariance) compositional biplot (Aitchison and Greenacre, 2000). The length of an arrow in a biplot is proportional to the variance of its associated variable, and the cosine of the angle between two arrows is related to the correlation coefficient between the two variables. These rules apply to both clr-transformed variables (arrows) and to pairwise log-ratios (links between two arrows). A biplot is a 2D graphical representation of the components and the individual samples, based on principal component analysis (PCA) of the clr-transformed data set. In a covariance biplot, variables are represented as rays: their length represents the variance of each variable, and the cosines of the angles between them approximate their correlation coefficient. Each arrow points towards the direction of enrichment in that element, thus individual samples are richer in the surrounding components. More details can be found in Caracciolo et al. (2012) and Tolosana-Delgado (2012-this issue).

The relationship between compositions and potentially explaining factors may be displayed by making use of pairwise log-ratios. Each of the $D(D-1)$ possible pairwise log-ratios can be plotted against any explanatory variable, either in the form of a scatterplot if the variable is continuous, or as a boxplot if it is categorical. The resulting $D(D-1)$ plots may be arranged in a $\mathrm{D} \times \mathrm{D}$ matrix of diagrams, where a plot represents the ratio of the component in the row divided by the component in the column.

Canonical correlation analysis is a PCA-related technique. In this case a data set with two subsets of variables (in this case two different compositions) is analysed to determine which linear combinations of variables in the first group best correlate to those of the second group. We use this technique to find the pair of balances showing the largest correlation.

Finally, scatterplots and ternary diagrams are used here to represent confidence regions on the means of the data set (or a data subset). In both cases, these are ellipses centred at the empirical mean of the data set. The ratio and orientation are respectively defined by the eigenvalues and eigenvectors of the variance-covariance matrix of the data set, with a radius proportional to the $95 \%$ quantile of the Fisher F-distribution with 2 and $\mathrm{N}-2$ degrees of freedom, where $\mathrm{N}$ is defined as the number of data points used to derive the mean and covariance. Confidence ellipses may be displayed in a ternary diagram by backtransforming all log-ratio points of the ellipse to obtain their equivalent composition vectors. In both scatterplots and ternary diagrams, these ellipses define the smallest region in which the mean of the data set is located with 95\% confidence (see Weltje, 2002 for more details).

\subsubsection{Poisson regression}

Working with means and covariances is particularly sensible if data can be assumed to follow an underlying normal distribution. This might be the case when working with geochemical data sets, but it is arguable when the composition was derived from a "few" counts. In this contribution, this is relevant for the petrographic compositions, i.e. the vector of 5 numbers giving the times that we counted a crystal of quartz, of plagioclase, of K-feldspar, of mica or of a dense mineral. Interface data (formed by the 15 possible pairs of minerals out of these 5 groups) fall also in this category. We consider interfaces between 5 different mineral classes (quartz, K-feldspar, plagioclase, micas and dense minerals), respectively denoted by the capital letters Q, K, P, M and D.

To work with interface counts, one must distinguish between the number of times an interface occurs and the proportion of that interface type. For minerals $i, j$, we denote by $x_{i j}$ the number of times that interface was found out of $M$ counts, and by $p_{i j}$ its (theoretical) proportion. Note that the vector of 15 proportions $\mathbf{p}=\left[p_{11}, p_{12}, \ldots\right.$, $\left.s p_{i j}, \ldots, p_{45}, p_{55}\right]$ forms a composition, while the vector of 15 counts does not. In fact, if $M=\sum_{i \geq j}^{5} x_{i j}$ is large, one can reasonably estimate the proportions as $\hat{p}_{i j}=x_{i j} / M$, but for small $M$ counting uncertainties matter. In particular, if we consider $M$ fixed, the vector $\mathbf{x}=$ 


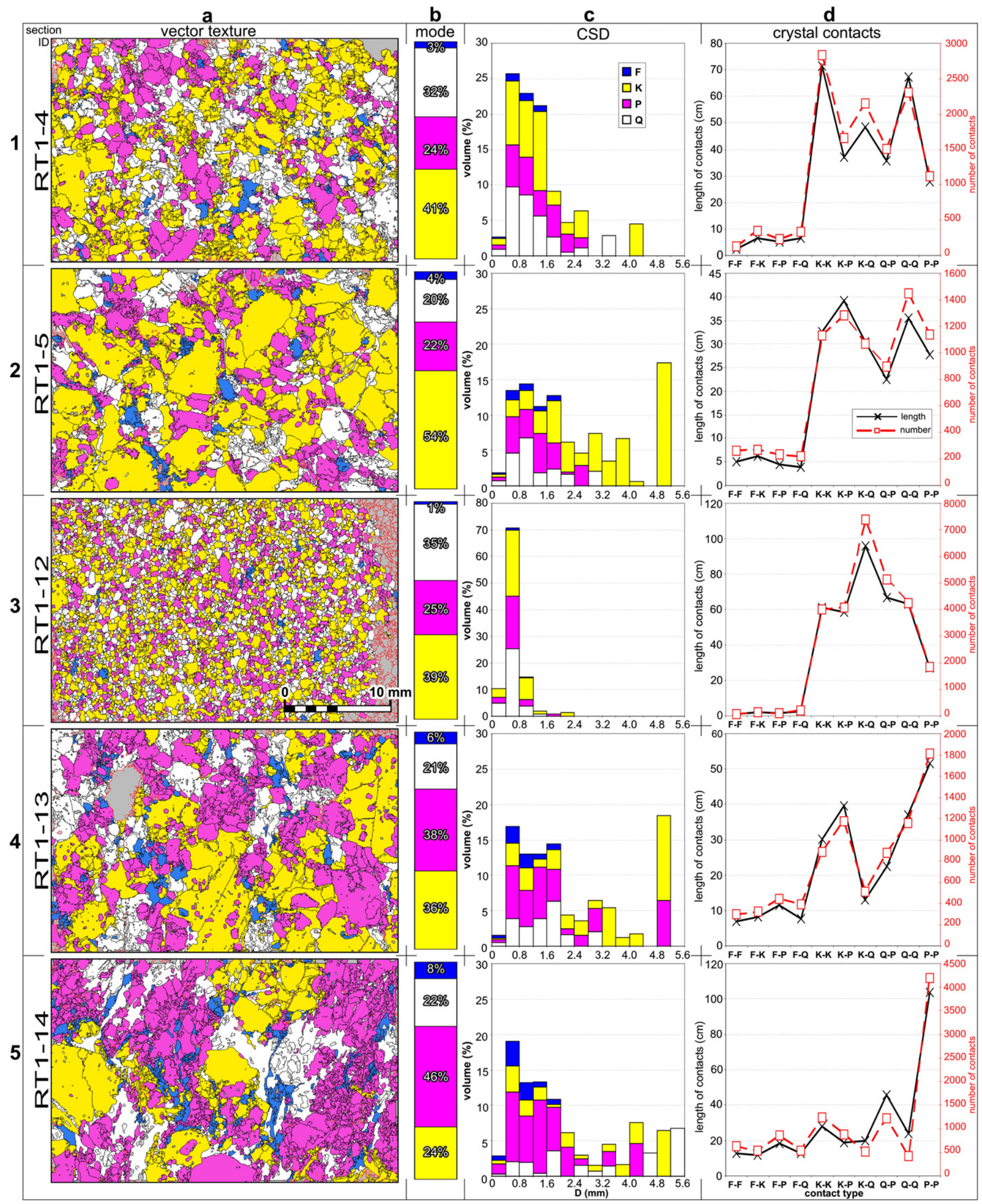

Fig. 2. Panels are arranged in five rows and four columns identified by numbers and letters, respectively. Each row contains data relating to a single sample, identified by the label on the far left. (a) map of crystals; (b) mode; (c) CSDs of the four mineral phases; and (d) interfaces plotted as cumulative length and raw number for each type of contact. The colour legend shown in panel $\mathrm{c} 1$ applies to columns $\mathrm{a}, \mathrm{b}$ and $\mathrm{c}(\mathrm{F}=$ femic minerals, $\mathrm{K}=\mathrm{K}$-feldspar, $\mathrm{P}=$ plagioclase, $\mathrm{Q}=$ quartz); the legend in panel $\mathrm{d} 2$ applies to column $\mathrm{d}$. Scale bar in panel a3 applies to all maps. In crystal maps, red contours over a grey background enclose: (i) unidentified crystals (e.g. far right side of panel a3), or (ii) holes in the thin section (e.g. upper left from centre in panel a4). 
Table 2

Average interface abundance in parent rock (measured by MIS), compared with predicted interface abundance for a sediment of $\mathrm{phi}=-10$, thus representing the result of the first steps of breakdown. The last two columns show enrichment factors relative to PP abundance, due to breakdown process.

\begin{tabular}{|c|c|c|c|c|c|c|}
\hline \multirow[t]{2}{*}{ IF type } & \multicolumn{2}{|c|}{ Source rock } & \multicolumn{2}{|c|}{$\begin{array}{l}\text { Predicted source rock } \\
(\mathrm{phi}=-10)\end{array}$} & \multicolumn{2}{|c|}{$\begin{array}{l}\text { Enrichment factors } \\
\text { relative to PP }\end{array}$} \\
\hline & Plutonic & Metamorphic & Plutonic & Metamorpic & Plutonic & Metamorpic \\
\hline MM & 1.46 & 5.65 & 7.80 & 8.06 & 5.26 & 0.88 \\
\hline KM & 2.15 & 4.85 & 8.34 & 8.01 & 3.82 & 1.02 \\
\hline PM & 1.89 & 7.77 & 10.46 & 10.70 & 5.43 & 0.85 \\
\hline QM & 2.19 & 4.92 & 11.46 & 11.93 & 5.14 & 1.50 \\
\hline KK & 16.63 & 11.28 & 8.92 & 8.86 & 0.53 & 0.49 \\
\hline $\mathrm{KP}$ & 14.63 & 7.88 & 9.47 & 8.55 & 0.64 & 0.67 \\
\hline QK & 19.11 & 4.65 & 10.05 & 9.82 & 0.52 & 1.31 \\
\hline QP & 14.41 & 11.08 & 10.87 & 11.02 & 0.74 & 0.62 \\
\hline QQ & 16.82 & 3.85 & 11.49 & 12.07 & 0.67 & 1.94 \\
\hline PP & 10.72 & 38.08 & 11.15 & 10.97 & - & - \\
\hline
\end{tabular}

$\left[x_{11}, \ldots, x_{i j}, \ldots, x_{55}\right.$ follows a Poisson distribution with probability vector the true proportions $\mathbf{p}$.

If $M$ is considered random and Poisson distributed with rate $\lambda$, then each interface count is also a random Poisson with expected counts $i j=\cdot p_{i j}$. This is the model followed in this contribution, where the Poisson rate of each possible interface $\lambda_{i j}$ is considered a function of the grain size (in $\phi$ scale), its parent rock texture (so, either plutonic or metamorphic) and the environment where it was deposited (env, one of front moraine, side moraine or washed). To mathematically describe the model, each of these factors is associated with a switcher function $I$ (condition), which is valued $I=1$ if the condition is true and $I=0$ if it is false. For instance, $I(s o=m)=1$ for grains of metamorphic texture and $I(s o=m)=0$ for grains of plutonic texture. Using these functions, we model the individual counts as:

$$
\begin{aligned}
\ln _{i j}= & {\left[a_{Q Q}^{p f}+b_{i j}^{p f}+c_{i}^{p f}+c_{j}^{p f}\right]+\left[a_{Q Q}^{\phi}+b_{i j}^{\phi}+c_{i}^{\phi}+c_{j}^{\phi}\right] \phi } \\
& +\left[a_{Q Q, m}^{s O}+b_{i j, m}^{s}+c_{i, m}^{s 0}+c_{j, m}^{s o}\right] I(s o=m) \\
& +\left[a_{Q Q, s}^{e n v}+b_{i j, s}^{e n v}+c_{i, s}^{e n v}+c_{j, s}^{e n v}\right] I(e n v=s) \\
& +\left[a_{Q Q, w}^{e n v}+b_{i j, w}^{e n v}+c_{i, w}^{e n v}+c_{j, w}^{e n v}\right] I(e n v=w) .
\end{aligned}
$$

In this expression, coefficient $a_{Q Q}^{\phi}$ represents the increase (or decrease) of expected $Q Q$ counts; coefficient $b_{l j}^{p f}$ represents the difference of expected counts between interface $i j$ and $Q Q$ on plutonic grains from a front moraine; coefficient $c_{i, s}^{e n v}$ represents the difference between the marginal frequency of occurrence between mineral $i$ and mineral $Q$ in a side moraine with respect to a front moraine; etc. Mineral quartz, front moraine as environment and plutonic grain as parent texture act as reference levels, from which all differences are computed. All these coefficients are estimated with a maximum likelihood standard procedure called Poisson regression. If a coefficient is estimated as zero, this implies that the associated factor has the same behaviour as the reference level. For instance, if $b_{i j}^{\phi}=0$ then all interfaces would occur with the same chances for all grain sizes. If front and side moraines would behave equally, then $a_{Q Q, s}^{e n v}=b_{i j, s}^{e n v}=$ $c_{i, s}^{e n v}=c_{j, s}^{e n v}=0$. Or if plagioclase and quartz occur exactly with the same frequency in plutonic grains from front moraines, then $c_{P}^{p f}=0$. Generally, a positive coefficient implies an increase of expected counts, while a negative coefficient means a decrease of expected counts. Thus, one may expect that $c_{M}^{\phi}>0$, because micas are naturally enriched in finer fractions (with larger $\phi$ ); or that $c_{D}^{p f}<0$ because plutonic rocks have much less dense minerals than quartz.

Table 3

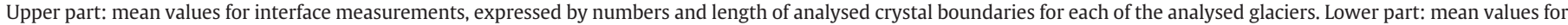

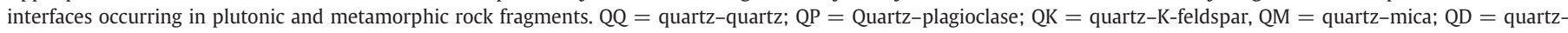

\begin{tabular}{|c|c|c|c|c|c|c|c|c|c|}
\hline \multirow[b]{3}{*}{ Mean } & \multicolumn{3}{|c|}{ Rhone glacier } & \multicolumn{6}{|c|}{ Damma + Sidelen } \\
\hline & \multicolumn{3}{|c|}{ Monzogranite } & \multicolumn{3}{|c|}{ Monzogranite } & \multicolumn{3}{|l|}{ Gneiss } \\
\hline & \multicolumn{2}{|c|}{ Number and \% } & Interface length (mm) & \multicolumn{2}{|c|}{ Number and \% } & \multirow{2}{*}{$\begin{array}{c}\text { IF length } \\
76.19\end{array}$} & \multicolumn{2}{|c|}{ Number and \% } & \multirow{2}{*}{$\begin{array}{c}\text { IF length } \\
235.21\end{array}$} \\
\hline $\mathrm{Fm}-\mathrm{Fm}$ & 193 & 1.88 & 70.13 & 181 & 1.03 & & 622 & 5.65 & \\
\hline Fm-Kf & 309 & 3.01 & 60.31 & 225 & 1.29 & 47.85 & 534 & 4.85 & 111.24 \\
\hline Fm-Pl & 233 & 2.27 & 51.62 & 266 & 1.52 & 60.32 & 856 & 7.77 & 170.89 \\
\hline Fm-Qz & 279 & 2.71 & 43.07 & 292 & 1.67 & 49.11 & 542 & 4.92 & 122.94 \\
\hline Kf-Kf & 1979 & 19.25 & 978.67 & 2449 & 14.00 & 856.80 & 1242 & 11.28 & 522.00 \\
\hline Kf-Pl & 1469 & 14.29 & 410.00 & 2618 & 14.97 & 461.62 & 868 & 7.88 & 178.06 \\
\hline $\mathrm{Kf}-\mathrm{Qz}$ & 1609 & 15.65 & 317.90 & 3948 & 22.57 & 511.33 & 512 & 4.65 & 187.55 \\
\hline Qz-Pl & 1203 & 11.70 & 273.28 & 2995 & 17.12 & 418.45 & 1220 & 11.08 & 434.92 \\
\hline $\mathrm{Qz}-\mathrm{Qz}$ & 1877 & 18.26 & 966.67 & 2690 & 15.38 & 941.78 & 424 & 3.85 & 445.41 \\
\hline Pl-Pl & 1130 & 10.99 & 523.04 & 1826 & 10.44 & 743.46 & 4194 & 38.08 & 1954.71 \\
\hline Total & 10,281 & 100.00 & 3694.71 & 17,490 & 100.00 & 4166.91 & 11,014 & 100.00 & 4362.93 \\
\hline
\end{tabular}

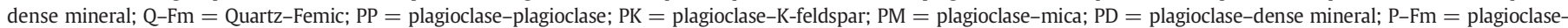

\begin{tabular}{|c|c|c|c|c|c|c|c|c|c|}
\hline \multirow[b]{3}{*}{ IF type } & \multicolumn{9}{|c|}{ Interfaces in sediments (total) } \\
\hline & \multicolumn{4}{|c|}{ Interfaces in plutonic rock fragments } & \multicolumn{5}{|c|}{ Interfaces in metamorphic rock fragments } \\
\hline & IF number & Expected nr. & Interface \% & Discrepancy & IF type & IF number & Expected nr. & Interface \% & discrepancy \\
\hline QQ & 2860 & 2322 & 19.60 & 0.09 & QQ & 1186 & 926 & 24.64 & 0.11 \\
\hline PP & 2436 & 2613 & 16.69 & -0.03 & $\mathrm{QP}$ & 814 & 682 & 16.91 & 0.08 \\
\hline QP & 2203 & 2463 & 15.10 & -0.05 & $\mathrm{PP}$ & 544 & 723 & 11.30 & -0.12 \\
\hline KP & 1645 & 1308 & 11.27 & 0.10 & PFm & 519 & 556 & 10.78 & -0.03 \\
\hline PFm & 1356 & 1256 & 9.29 & 0.03 & FmFm & 511 & 267 & 10.62 & 0.28 \\
\hline QK & 1190 & 1233 & 8.15 & -0.02 & QFm & 509 & 524 & 10.58 & -0.01 \\
\hline FmFm & 965 & 603 & 6.61 & 0.20 & QK & 284 & 235 & 5.90 & 0.08 \\
\hline QFm & 949 & 1184 & 6.50 & -0.10 & KK & 201 & 125 & 4.18 & 0.21 \\
\hline KK & 588 & 655 & 4.03 & -0.05 & $\mathrm{KP}$ & 158 & 250 & 3.28 & -0.20 \\
\hline KFm & 401 & 628 & 2.75 & -0.19 & $\mathrm{KFm}$ & 87 & 278 & 1.81 & -0.50 \\
\hline
\end{tabular}

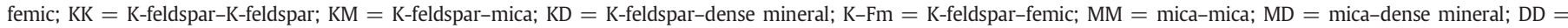
dense mineral-dense mineral, and $\mathrm{Fm}-\mathrm{Fm}=$ femic-femic. 


\section{Results}

\subsection{Parent rock: texture and composition}

Analysed samples are fresh to weakly weathered and preserve the pristine petrographic structure of the parent rock. Alteration mainly affects feldspars and biotite. Plagioclase is slightly altered to clays and sericite, or to epidote, whereas K-feldspar is rarely affected by argillification. Biotite is partially altered to chlorite along cleavage planes, probably as a result of deuteric processes. K-feldspar commonly shows albitization features.

The MIS was used to obtain the modal composition and crystal size distribution (CSD) of parent rocks, and the type and length of mineral interfaces (Fig. 2). A total of 12,412 crystals were assigned to one of the four mineral groups (Q-K-P-F) and measured and processed for mineral interface analysis (Table 1 ).

Based on the modal composition of the parent rock, the basement drained by the Rhone glacier may be classified as a medium grained monzogranite (Fig. 2). A heterogranular porphyritic texture, showing euhedrality, mostly in plagioclases and subordinately in K-feldspars is typical of the two analysed samples. Quartz and femic grains are sub-euhedral to anhedral. The CSD analysis indicates that plagioclase and quartz crystals are mostly concentrated within the $400 \mu \mathrm{m}$ to $3.2 \mathrm{~mm}$ interval. K-feldspars show a higher variability, reaching a coarser grain size, between 3 and $5 \mathrm{~mm}$ (especially in sample RT1-5). Femic minerals are mostly represented by biotite grains, ranging in dimension between $400 \mu \mathrm{m}$ and $1.6-2 \mathrm{~mm}$. Biotite commonly shows a topotactic crystallisation including rutile crystals and is often altered to chlorite. Dense minerals are hornblende, epidote, titanite, zircon and rutile.

According to their modal composition (Fig. 2 column c), the three granitoid samples draining the Damma and Sidelen glaciers are monzogranite (RT1-12; RT1-13) and orthogneiss (RT1-14). Rocks drained by the Sidelen and Damma glaciers are richer in plagioclase and femic crystals compared to the monzogranites of the Rhone glacier. Sample RT1-12 is a fine-grained monzogranite showing aplitic texture. This sample exhibits an autoallotriomorphic equigranular texture with $72 \%$ of crystals ranging in dimension between $400 \mu \mathrm{m}$ and $800 \mu \mathrm{m}$ (Fig. 2.3c). Sample RT1-13 is a medium-grained heterogranular porphyritic monzogranite. K-feldspar grains are mostly euhedral whereas plagioclase, quartz and femic crystal vary from sub-euhedral to anhedral. $55 \%$ of crystals are concentrated within the $400 \mu \mathrm{m}$ to $2 \mathrm{~mm}$ interval. Feldspars are coarser, with a number of K-feldspars and plagioclases ranging in dimension from $3 \mathrm{~mm}$ to $5 \mathrm{~mm}$. Femic minerals are comprised between $400 \mu \mathrm{m}$ and $2 \mathrm{~mm}$.

Sample RT1-14 is a medium grained gneiss showing a moderately porphyritic texture. K-feldspar grains are sub-euhedral to euhedral whereas plagioclase, quartz, and femic crystals range from sub-euhedral to anhedral. Plagioclase grains are arranged in glomerophyric clusters composed of a number of smaller crystals. This complex texture of plagioclase, together with local higher incidence of alterations, posed difficulties to detection of intra-plagioclase crystal boundaries (Fig. 2.5a). Most of the observed quartz consists of elongated, polycrystalline aggregates, trending along the direction of preferential crystal alignments (Fig. 2.5c). Similarly to sample RT1-13, 54\% of the crystals are concentrated within the $400 \mu \mathrm{m}$ to $2 \mathrm{~mm}$ interval.

A total of 66,555 contacts were determined by interface analysis among quartz, plagioclase, K-feldspar and femic phases ( $\sim 13.5 \mathrm{~m}$ total contact length; Sedimentary Geology OSM). Results indicate that isomineralic interfaces develop longer crystal boundaries (Fig. 2, column d). According to CSD and modal composition, interfaces involving K-feldspar crystals are the most important (Tables 2 and 3), with KK interfaces dominating in the monzogranite from the Rhone glacier and $\mathrm{QK}$ and $\mathrm{PK}$ interfaces playing a relevant role within the whole set of analysed samples. Isomineralic QQ interface frequency is the second
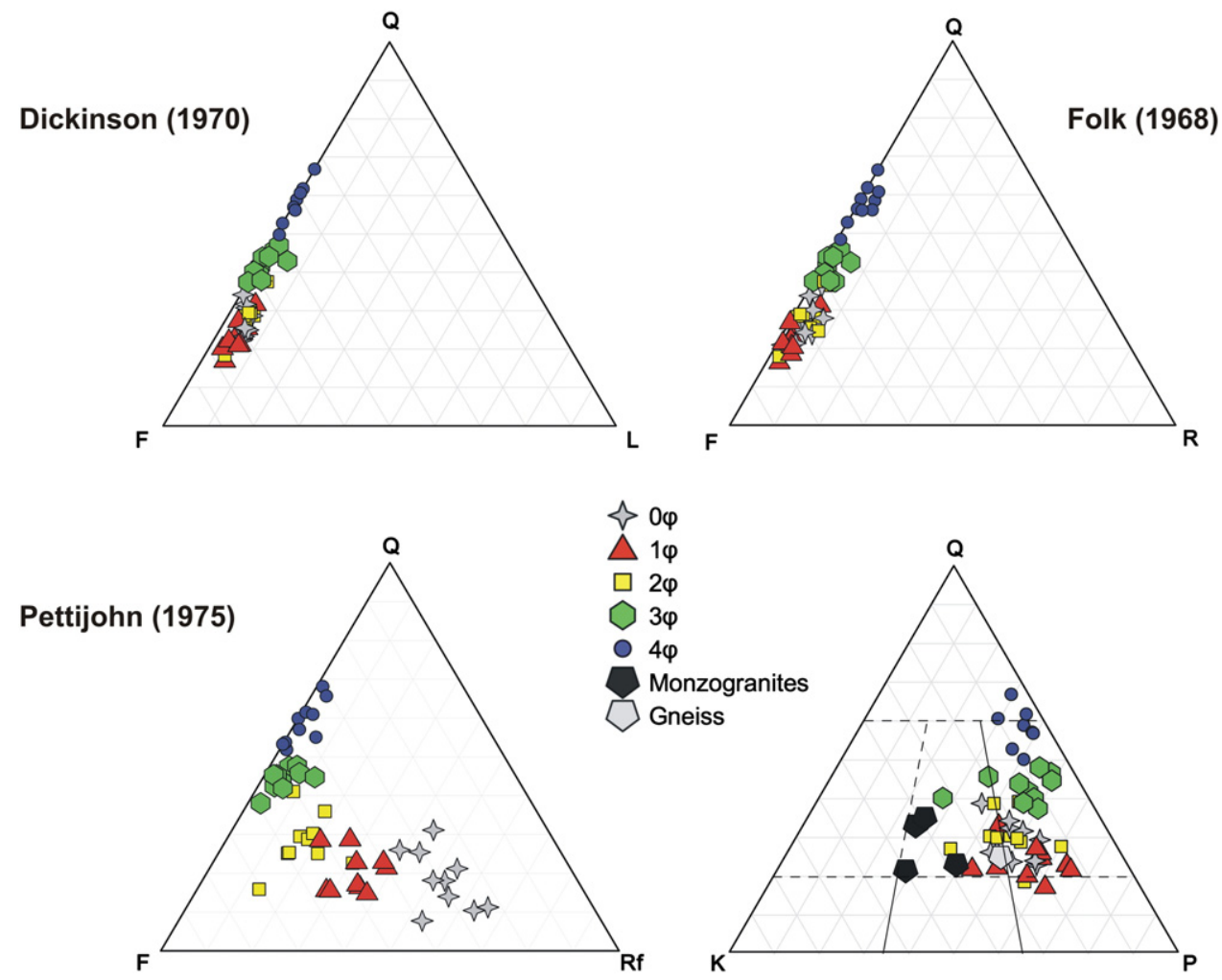

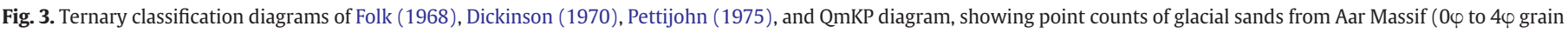

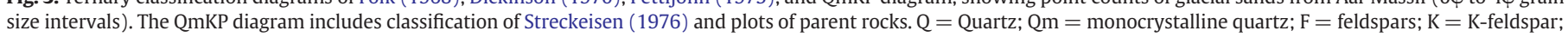
$\mathrm{P}=$ Plagioclase; $\mathrm{R}$ and $\mathrm{Rf}=$ rock fragments; and $\mathrm{L}=$ aphanitic lithic fragments. 
highest after KK, whereas QP frequency is small. PP interfaces are of particular importance for samples from the Damma glaciers. Interfaces involving femic phases do not show any particular pattern.

\subsection{Glacial sands}

\subsubsection{Grain size}

Analysed samples are, in most of the cases, classified as poorly sorted very coarse sands; some are medium to very fine sands. The coarsest sediments were sampled from the side of the moraine. Finer deposits are found at the front of the moraine or at the streams flowing out from the glacier.

\subsubsection{Petrology}

Traditional and interface point-counting results and recalculated parameters of analysed sands are reported in the online supplementary material. QFL (Dickinson, 1970), QFR (Folk, 1968), and QFRf (Pettijohn, 1975) classifications are reported in Fig. 3.

According to the Folk and Dickinson classifications, analysed sands are arkosic arenites, whereas the Pettijohn scheme yields a strongly grain-size dependent classification into feldspathic litharenitic

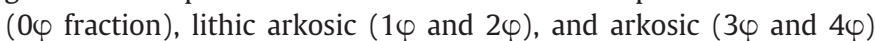
compositions.

The Pettijohn classification perfectly describes the evolution of rock fragments and monomineralic quartz and feldspar grains as a function of grain-size reduction. Compositional variation within the sediments is accompanied by textural modification. Very coarse sands are characterised by the dominance of well-rounded rock fragments and monocrystalline grains (especially plagioclases), whereas angular grains dominate in finer sands (Fig. 4). The degree of roundness decreases with increasing grain-size class, with medium sands having approximately identical proportions of rounded and angular grains. Petrographic indices, such as $\mathrm{P} / \mathrm{F}$ and $\mathrm{Q} / \mathrm{F}$, show large variations
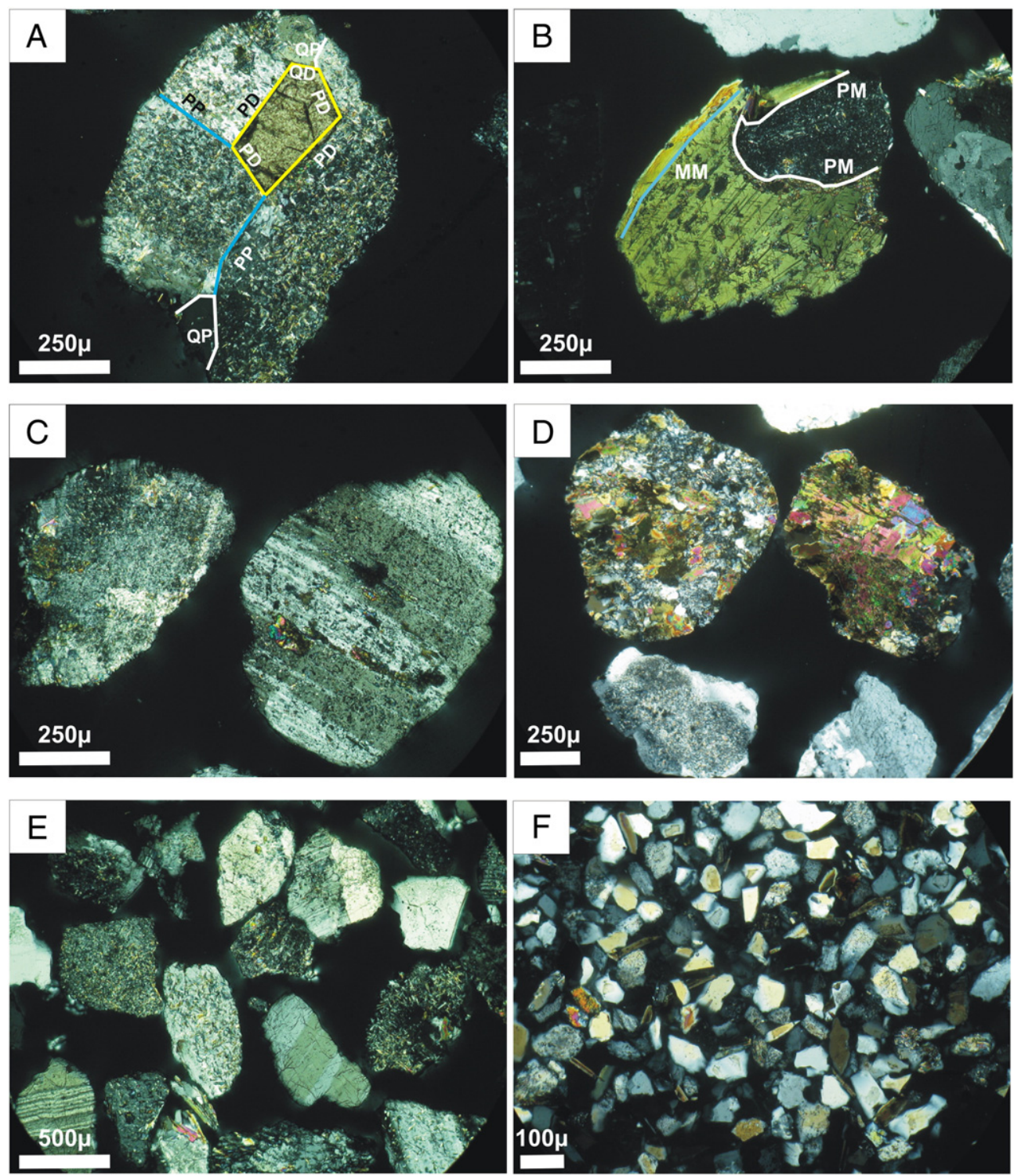

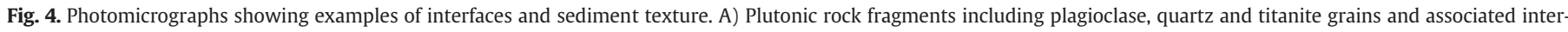

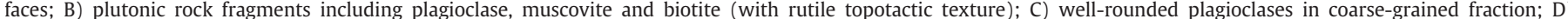

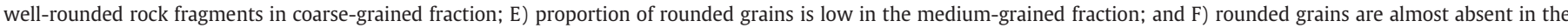

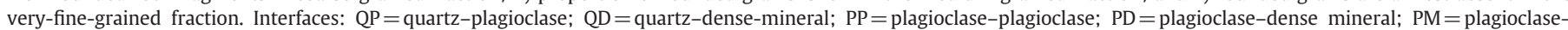
mica; and $\mathrm{MM}=$ mica-mica. 


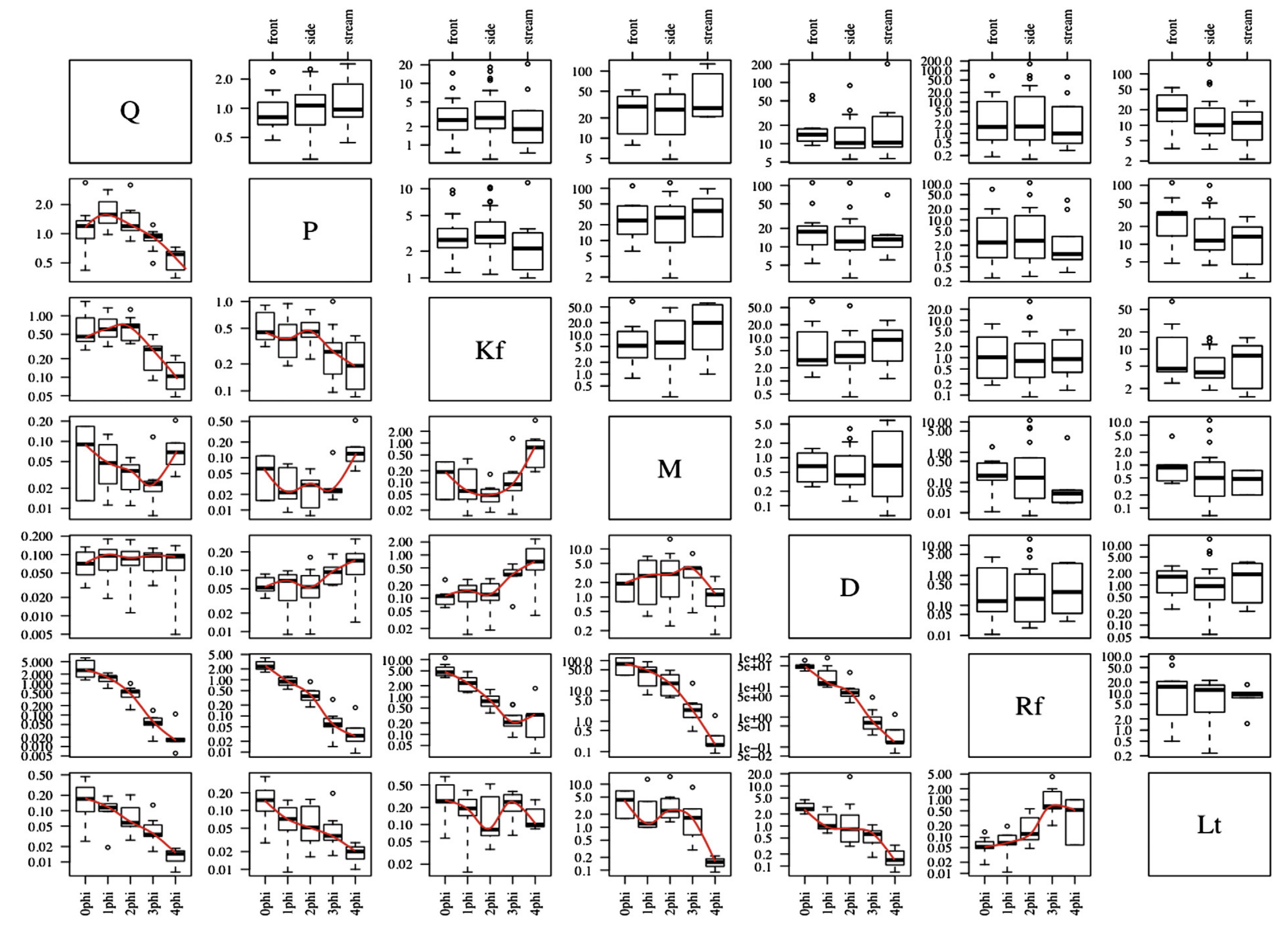

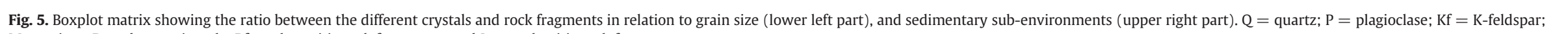
$\mathrm{M}=$ micas; $\mathrm{D}=$ dense minerals; $\mathrm{Rf}=$ phaneritic rock fragments; and $\mathrm{Lt}=$ aphanitic rock fragments. 

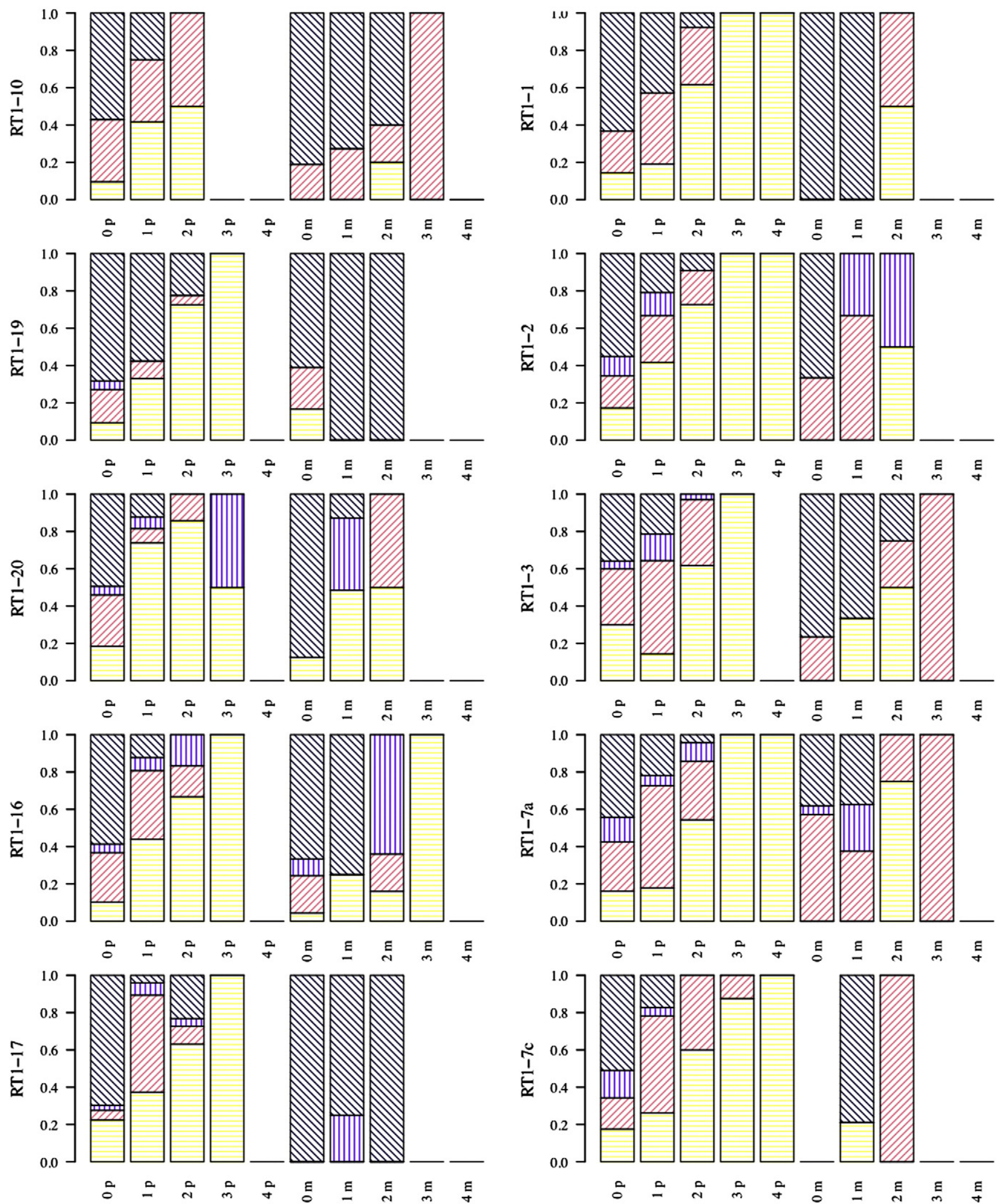

\section{$\square \quad 3 \mathrm{c} \quad \square \quad 4 \mathrm{c} \quad$ 血 $5 \mathrm{c} \quad \mathbb{Q}+5 \mathrm{c}$}

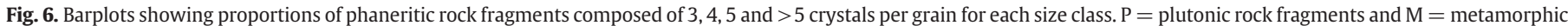
rock fragments. 
with grain size. In the $2 \varphi$ fraction, $\mathrm{P} / \mathrm{F}$ ratios reflect a slight dominance of plagioclase over K-feldspar, whereas $\mathrm{Q} / \mathrm{F}$ ratios are characterised by values which are similar to those of parent rocks.

Quartz grains consist of monocrystalline quartz, aphanitic polycrystalline quartz showing tectonic fabric, and phaneritic composite quartz which cannot be unequivocally attributed to plutonic or metamorphic sources. Plagioclases are of anorthitic composition, characterised by clear evidence of epidotization and minor sericitization. $\mathrm{K}$-feldspars are mostly microcline and subordinate oligoclase. Micas are represented by topotactic biotite with rutile inclusions (Fig. 4b), often altered to chlorite, and, in lower concentrations, by muscovite and chlorite. Dense minerals are represented by green hornblende, epidote, titanite, tourmaline, zircon and rutile in order of decreasing abundance. Besides common granitic and gneissic rock fragments, coarse grained mica-schists and phyllite fragments occur in small proportions.

Modal compositions of granitoid sands vary with grain size. Sands of the $0 \varphi$ fraction plot close to the Rf pole $\left(\mathrm{Q}_{3} \mathrm{~F}_{24} \mathrm{Rf}_{73}\right)$, whereas sands of the $2 \varphi \phi$ fraction plot close to the $\mathrm{F}$ pole $\left(\mathrm{Q}_{22} \mathrm{~F}_{55} \mathrm{Rf}_{23}\right)$, and those of the $4 \varphi$ fraction plot close to the $\mathrm{Q}$ pole $\left(\mathrm{Q}_{65} \mathrm{~F}_{31} \mathrm{Rf}_{4}\right)$.
These means are all placed along a trend, characterised by a constant (Figs. 5 and 7A):

$\ln \left(\mathrm{F}^{11} /\left(\mathrm{Rf}^{2} * \mathrm{Q}^{9}\right)\right) \approx 0.868$

\subsubsection{Petrographic trends}

A detailed representation of petrographic trends is given in Fig. 5. Boxplots of ratios between rock fragments or lithic fragments vs. main mineral phases show a drastic decrease of the former relative to the latter with decreasing grain size. Proportions of quartz and feldspars grains indicate a dominance of plagioclases and K-feldspars $(\mathrm{F} / \mathrm{Q} \sim 2: 1)$ in $0 \varphi$ and $2 \varphi$ intervals, whereas in medium to very fine sands this trend is reversed $(\mathrm{F} / \mathrm{Q} \sim 1: 2)$. K/P ratios decrease with grain size. Ratios between micas, quartz and feldspar grains document negligible contents in coarser to medium fractions and a marked increase in finer grain sizes, as shown by $\mathrm{M} / \mathrm{P}$ and $\mathrm{M} / \mathrm{K}$ ratios. $\mathrm{M} / \mathrm{Q}$ and $\mathrm{F} / \mathrm{Q}$ ratios indicate that micas and quartz are the most important
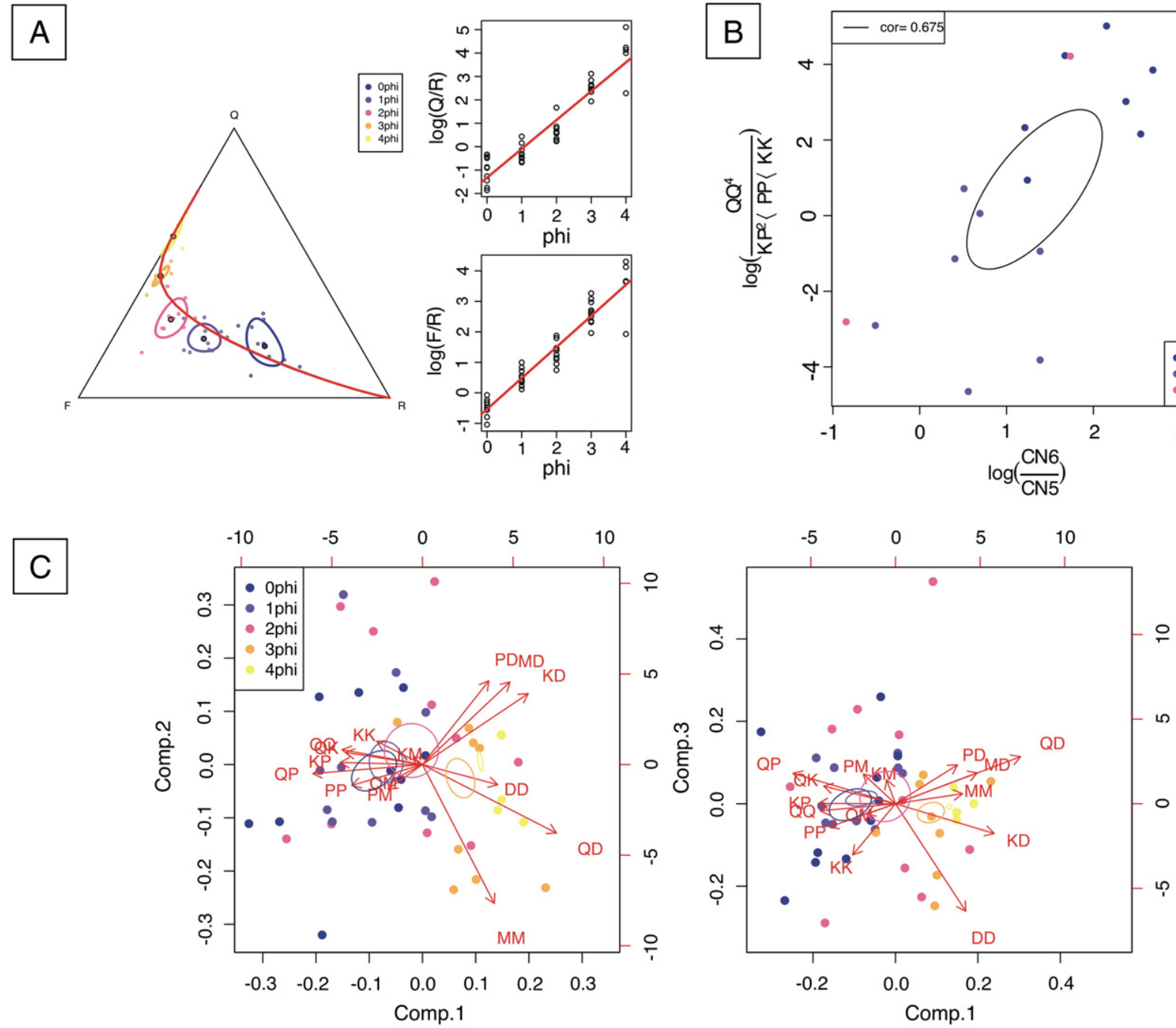

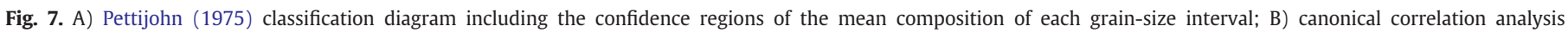

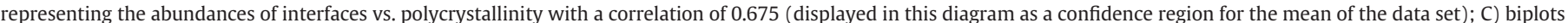

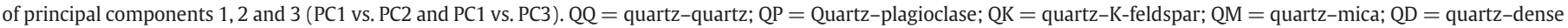

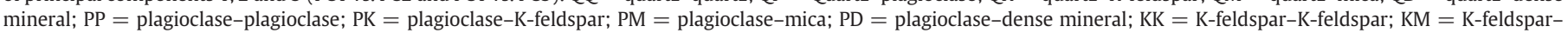
mica; $\mathrm{KD}=\mathrm{K}$-feldspar-dense mineral; $\mathrm{MM}=$ mica-mica; $\mathrm{MD}=$ mica-dense mineral; and $\mathrm{DD}=$ dense mineral-dense mineral. 
components of $3 \varphi$ and $4 \varphi$ grain sizes. The abundance of dense minerals follows a trend similar to micas.

The three sub-environments do not show significant differences: within-environment variability generally exceeds the variability between environments. The only exception is a slight increase in the abundance of $\mathrm{M}$ relative to all other components in the stream sediments, where hydrodynamic sorting processes dominate.

\subsubsection{Interfaces}

Polycrystallinity of phaneritic rock fragments and associated interfaces are reported in Figs. 6 and 7. The number of crystals within plutonic and coarse-grained metamorphic rock fragments shows the largest variability within plutonic derived material (Fig. 6). In most of the cases, monzogranite fragments include $>5$ and 4 crystals per rock fragment in $0 \varphi$ and $1 \varphi$ grain sizes, and the $2 \varphi$ to $4 \varphi$ grain sizes are dominated by rock fragment consisting of 2 to 3 crystals. Metamorphic detritus shows less variability, with rock fragments consisting of five and more crystals dominating the $0-2 \varphi$ intervals.

The distribution of interfaces across the grain size intervals is reported in Sedimentary Geology OSM and Fig. 7. The three branches shown in the biplot of interface data provide information for characterising the sediments generated in glacial environments (Fig. 7C). Interfaces among quartz, plagioclase, K-feldspar and micas, group together in the left branch of the biplot. The association of QQ-QK, QP-PK, and QM-PM interfaces shows a high degree of dependence, whereas KK and PP show a wider angle suggesting a lesser degree of dependence. Dense mineral interfaces PD, MD, and KD cluster in the right-hand part of the biplot, whereas DD and QD appear to be more independent. Isomineralic MM interfaces represent a separate group. Each of these associations tends to occur in specific grain size intervals. Iso- and non-isomineralic interfaces involving quartz, feldspars and micas are particularly abundant in $0 \varphi, 1 \varphi$ and $2 \varphi$ grain sizes, whereas their occurrence decreases in favour of interfaces including dense minerals (PD-MD-KD-QD-DD), which are more common in $3 \varphi$ and $4 \varphi$ intervals. Isomineralic MM interfaces reach their highest concentrations in the $3 \varphi$ fraction.

These descriptive results are consistent with more rigorous Poisson regression, in which the explanatory power of grain size, parent rock texture (plutonic vs. metamorphic), and depositional environment (front moraine vs. side moraine vs. fluvial washed) have been statistically tested. Table 4 shows which of these effects is statistically significant (P-value $<0.001$ ). Interpretation of the regression coefficients is guided by Eq. (1): positive coefficients imply a higher abundance than expected under the assumption of randomness, whereas negative coefficients imply a lower abundance.

Pure interface effects (Table 4) show that P and Q have similar abundances, while K-feldspar is reduced by a factor of $\sim 50 \%(\exp (-0.74)=$ 0.48 ), and mica and dense minerals by 0.37 and 0.03 , respectively. This combines to a sort of coarse sand marginal mineral abundance proportional to $[1.0,1.0,0.48,0.37,0.03]=[35,35,16,13,1] \%$, consistent with the composition of detritus derived from granitoid rocks (Fig. 3, QmKP). Dense minerals show a general enrichment with respect to expectations based on their marginal abundances (all coefficients for DM, DP and DD are positive). In contrast, K-feldspar interface abundances are less than expected from the marginal abundance of $\mathrm{K}$ (KK and KM coefficients are negative). Grain-size influences imply a general reduction of interfaces towards finer fractions by a factor of $\exp (-1.25)=0.29$ per phi unit. On the contrary, D and $\mathrm{K}$ are enriched relative to $\mathrm{Q}$ by 1.30 and 1.45 per phi unit, respectively. MM interfaces are also enriched towards finer fractions by a factor of $\exp (0.60)=1.80$ per phi unit $(80 \%$ enrichment). The abundance of all interfaces in metamorphic fragments is reduced by a factor of $\exp (-0.45)=0.64$ with respect to granitoid rock fragments. Feldspar-bearing rock fragments are mostly plutonic; MP and KK interface abundances are larger than expected in metamorphic rocks.
Side moraine rock fragments show a major enrichment in the dense minerals-to-quartz ratio by a factor of $\exp (1.09)=2.97$ (an increase of almost 200\%), and a slight increase in K-feldspar and micas (enrichment factors around 1.4 and 1.5, respectively). This results in significant increases of $\mathrm{MD}$ (factor $\exp (0.42+1.09-1.14)=$ 1.45) and DD (factor 2.7) interfaces with respect to the abundances of these interfaces relative to $\mathrm{QQ}$ in a front moraine. Stream sediments show a significant decrease of mica/quartz abundances (factor 0.65 , reduction of $35 \%$ ), as well as a general enrichment in interfaces not involving $\mathrm{Q}$ or $\mathrm{D}$, with enrichment factors in the range of $1.15(\mathrm{PM}, \mathrm{MM})$ and $2.3(\mathrm{KK})$.

As a consequence, coarser grains potentially have higher polycrystallinity than finer grains, and this might also have an influence on the relative abundances of each interface: $M$ and $D$ interfaces, being smaller, should be expected to dominate in the finer fractions, while $\mathrm{Q}-\mathrm{P}-\mathrm{K}$ interfaces would be more common in the coarser fractions. A canonical correlation analysis of the abundances of interfaces vs. polycrystallinity suggests the relationship expressed in Fig. 7B,

\section{Table 4}

Poisson regression model coefficients. Only coefficients with significance lower than 0.001 are shown. The intercept gives the expected counts of $\mathrm{OQ}$ interfaces on a coarse sand granitoid clast from a front moraine (reference setting). Each other coefficient represents the increase/decrease of the odds of finding a certain interface between two minerals on a particular parent rock, rock fragment of a specified grain size, and within a given environment, with respect to the reference QQ-granitoid-coarse sand-front moraine setting. Thus, for instance, the expected counts of MD interfaces on medium sand $(\mathrm{phi}=2)$ on a side moraine environment are $\exp (2 * 0.37-0.99-$ $3.4+1.7+0.42+1.09-1.14)=0.2$ times the expected counts of QQ interfaces on coarse sands front moraines ( $80 \%$ less). If reference QQ counts are $\exp (4.8)=120$ at front moraines from granitoid clasts, roughly we can expect 25 MD counts.

\begin{tabular}{|c|c|c|c|c|c|c|}
\hline \multicolumn{7}{|c|}{ Pure interface effects } \\
\hline Intercept & 4.8 & Q & $\mathrm{P}$ & $\mathrm{K}$ & M & $\mathrm{D}$ \\
\hline \multicolumn{7}{|c|}{ Q } \\
\hline & \multicolumn{5}{|l|}{$\mathbf{P}$} & \multirow[t]{2}{*}{0.89} \\
\hline-0.74 & \multicolumn{3}{|l|}{$\mathbf{K}$} & \multirow{2}{*}{$\begin{array}{l}-0.56 \\
-0.65\end{array}$} & \multirow[t]{2}{*}{-0.65} & \\
\hline-0.99 & M & & & & & 1.7 \\
\hline-3.4 & \multicolumn{2}{|l|}{ D } & \multicolumn{2}{|l|}{0.89} & 1.7 & 3.6 \\
\hline \multicolumn{7}{|c|}{ Grain-size effect } \\
\hline \multirow[t]{3}{*}{ GS } & -1.25 & \multirow[t]{6}{*}{ Q } & \multirow[t]{6}{*}{$\mathrm{P}$} & \multirow[t]{3}{*}{$\mathbf{K}$} & \multirow[t]{3}{*}{$\mathbf{M}$} & \multirow[t]{6}{*}{ D } \\
\hline & Q & & & & & \\
\hline & $\mathrm{P}$ & & & & & \\
\hline \multirow[t]{2}{*}{0.16} & $\mathbf{K}$ & & & & & \\
\hline & M & & & & \multirow[t]{2}{*}{0.6} & \\
\hline 0.37 & D & & & & & \\
\hline \multicolumn{7}{|c|}{ Source effect: metamorphic/plutonic } \\
\hline Met & $\begin{array}{l}-0.45 \\
Q\end{array}$ & Q & $\mathbf{P}$ & $\mathbf{K}$ & $\mathbf{M}$ & \multirow[t]{5}{*}{$\mathrm{D}$} \\
\hline-0.54 & $\mathbf{P}$ & & & & \multirow[t]{4}{*}{0.33} & \\
\hline \multirow[t]{3}{*}{-0.98} & $\mathbf{K}$ & & & 1.34 & & \\
\hline & $\mathbf{M}$ & & 0.33 & & & \\
\hline & $\mathrm{D}$ & & & & & \\
\hline \multicolumn{7}{|c|}{ Environment effects vs. front moraine } \\
\hline \multirow[t]{3}{*}{ Side } & 0.00 & \multirow[t]{6}{*}{ Q } & \multirow[t]{6}{*}{$\mathrm{P}$} & $\mathrm{K}$ & M & D \\
\hline & Q & & & & & \\
\hline & $\mathrm{P}$ & & & & & \\
\hline 0.33 & $\mathbf{K}$ & & & & & \\
\hline 0.42 & M & & & & & -1.14 \\
\hline 1.09 & D & & & & -1.14 & -1.18 \\
\hline Stream & 0.00 & Q & $\mathbf{P}$ & $\mathbf{K}$ & M & $\mathrm{D}$ \\
\hline & $Q$ & & & & & \\
\hline & $\mathbf{P}$ & & & 0.57 & 0.59 & \\
\hline & $\mathbf{K}$ & & 0.57 & 0.86 & & \\
\hline-0.43 & M & & 0.59 & & 1.00 & \\
\hline & $\mathrm{D}$ & & & & & \\
\hline
\end{tabular}


with a correlation of 0.675 (displayed as a confidence region for the mean of the data set). Accordingly, the larger presence of crystals of more than 5 crystals relative to those of exactly 5 crystals significantly increases the abundance of isomineralic QQ interfaces relative to the feldspar interfaces (KK, PP, PK). Other relations suggested by canonical correlations did not attain values greater than 0.5 .

\section{Discussion}

\subsection{Compositional signatures and grain-size}

Our analyses indicate that the basement drained by the Rhone, Damma and Sidelen glaciers is represented by medium to coarsegrained monzogranite, and gneiss. MIS analyses of the monzogranites indicate that K-feldspar is the overall dominant mineral and crystal phase (in some cases together with plagioclase), and reaches the coarsest size $(\sim 5 \mathrm{~mm})$. Interfaces involving $\mathrm{K}$-feldspar are the most abundant in terms of lengths and number of developed contacts, followed by quartz and plagioclase-related interfaces. Those including micas and dense minerals (femic) occur in minor concentrations (Tables 2 and 3).

Petrographic compositions of the sands do not match the composition of the parent rock. KK interfaces are underrepresented in sands with respect to parent rocks (Tables 2, 3). The QmKP ternary diagram (Fig. 3) shows how, in the whole grain size range, K-feldspar systematically occurs in smaller concentrations than quartz and plagioclase grains. Moreover, interface point counts indicate that the $\mathrm{QQ}>\mathrm{PP}>$ $\mathrm{QP}>\mathrm{PK}$ series is the most representative of the analysed dataset (Tables 2 and 3 ). These results indicate that there is a loss of $\mathrm{K}$-feldspar and KK-QK interfaces induced by erosional and transport processes. We documented that the increase of polycrystallinity corresponds to higher probabilities for QQ interfaces to occur. This suggests that comminution of rock fragments to monocrystalline grains is primarily influenced by this type of interface, whereas the role exerted by feldspars, micas and associated interfaces is negligible. Textural evidence in sediments, such as the relationship between the degree of roundness and grain-size variation, support this fact. Feldspar grains, particularly plagioclases, occur in coarser grain sizes as perfectly rounded grains. The same holds for mica-rich rock fragments and composite quartz grains, testifying to the combined effect of parent rock texture and comminution in glacial environments. The nature of feldspars within the Aar hypidiomorphic monzogranite favours early separation of coarse K-feldpars and plagioclases from parent rocks and rock fragments, indicating that breakdown is the dominant process for generating these types of grains. Albitization of K-feldspar also favours rapid destruction of this type of grain. von Eynatten et al. (2012-this issue) documented a $\mathrm{K}_{2} \mathrm{O}$ enrichment in the silt fraction from the same sample suite. This evidence indicates that at least a part of the K-feldspar is comminuted to a $5 \varphi$ size. On the other hand, the highest percentages of QQ interfaces in $3 \varphi$ and $4 \varphi$ intervals, together with the dominance of angular quartz grains, indicate that comminution is chiefly accomplished by abrasion.

\subsection{Comparisons to other plutoniclastic sands}

We compare our results to those of Tortosa et al. (1991) and Le Pera (provided as online supplementary material), who analysed sands derived from granitoids in similar (semi-arid) climates, but corresponding to different depositional environments and sampling scales (cf. Ingersoll, 1990). Sand samples included in Tortosa et al. (1991) were derived from fluvial deposits draining granitic and gneissic lithologies of the Iberian Central System. Sands from the San Gabriel Mountains and the Puente Capistrano Fm. (California) were deposited in fluvial and deep water environments respectively. A ternary plot including sample means of Aar, Iberian Central System and San Gabriel Mountains sands ( $4 \varphi$ and $5 \varphi$ classes) is reported in Fig. 8. Compositional trends show a general evolution varying from feldspathic litharenitic to lithic arkosic and arkosic compositions, paralleling the evolution of the sands analysed in this study. Similar compositional trends of samples from the Iberian Massif and the San Gabriel Mountains testify to the primary control exerted by parent rock texture, regardless of sedimentary environment and sampling scale. Small differences among sands are attributable to textural variations between granodiorites of the two orogenic systems. Compositions of glacial sands from the Aar Massif are comparable to both, although they contain lower amounts of rock fragments in the coarser fractions, and higher content of quartz

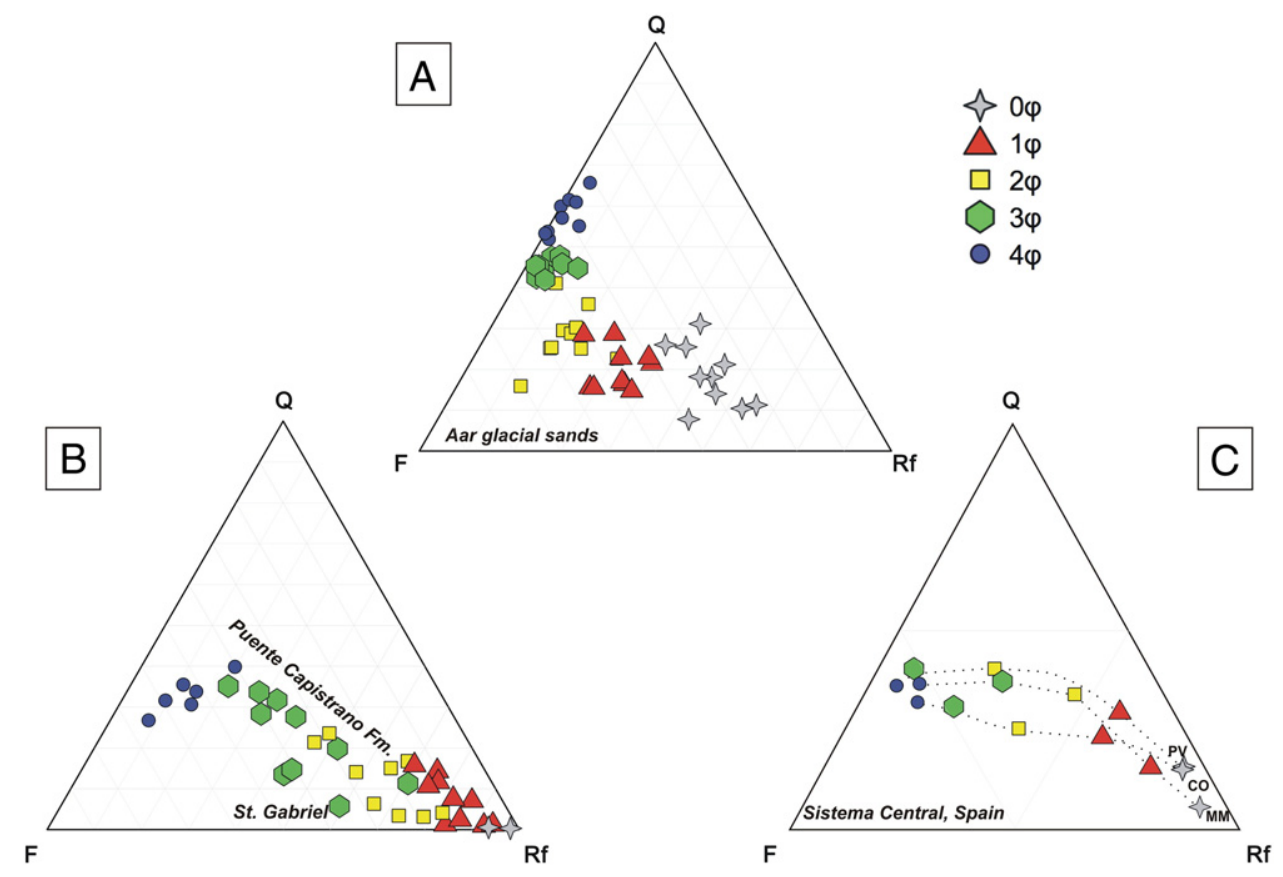

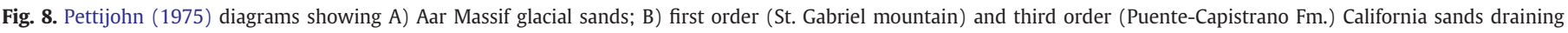

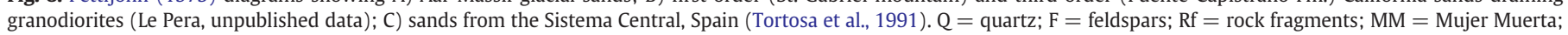
$\mathrm{CO}=$ Prado Redondo; and PV = El Purgatorio. 
grains, especially in finer fractions. These differences are not interpreted as depending on parent rock textures, but attributed to the high energy level of glacial transport and associated shear stresses acting on rock fragments, which caused their disaggregation.

\section{Conclusions}

The determination of parent rocks modal composition and crystal size distribution, as well as the measurements of crystal boundaries, has been pivotal in this study. The use of quantitative means, such as the Microscopic Information System, represents a step forward towards a thorough understanding (and hence possible prediction) of the relationships between parent rocks and generated sediments.

- Modal compositions obtained by MIS allowed classifying the Aar basement as a monzogranite, with a slight dominance of K-feldspars on plagioclases and quartz crystals.

- K-feldspar related interfaces are the most important, both in terms of numbers and length of developed surface boundaries.

- Point count on sediments yields a strongly grain-size dependent classification (Pettijohn et al., 1972) into feldspathic litharenitic ( $0 \varphi$ fraction), lithic arkosic ( $1 \varphi$ and $2 \varphi$ ), and arkosic $(3 \varphi$ and $4 \varphi$ ) compositions.

- Compositional and interface data for analysed sediments do not reflect those determined for the parent rock. Detrital K-feldspar and related interfaces loss is about $50 \%$, whereas plagioclase and quartz grains are moderately to strongly enriched respectively.

- The interface analysis indicates the $\mathrm{QQ}>\mathrm{PP}>\mathrm{QP}>\mathrm{PK}$ as the most representative series of interfaces, reflecting the highest mechanical preservation potential for this environment. This result confirms what assessed by Heins (1995) regarding the higher preservation potential of $\mathrm{PK}$ and $\mathrm{QK}$ non-isomineralic interfaces if compared to KK isomineralic bonds.

- Granitoid supplied fluvial and deep water deposits from Central Spain and California show identical grain size dependent compositional trends. Glacial sediments are characterised by lower rock fragment content in coarser sand and higher quartz concentration in medium to fine sand. This fact, together with the highest durability of QQ interfaces, suggests that instead of mechanical breakdown the comminution of quartzose grains mainly acts in terms of abrasion and grinding and consequent quartz splinters production, determining the described compositional anomaly.

\section{Acknowledgements}

We are grateful to Bill Heins, Abijit Basu, and a third anonymous reviewer, for their critical and constructive comments which helped to increase the quality of our manuscript. We specially acknowledge Gert Jan Weltje for sharing and discussing his ideas and his fundamental help in refining the last version of this paper. Funding was partly provided by the German Research Foundation (DFG), grant EY23/11 to Hilmar von Eynatten.

\section{Appendix A. Supplementary data}

Supplementary data to this article can be found online at http:// dx.doi.org/10.1016/j.sedgeo.2012.07.005.

\section{References}

Aitchison, J., 1982. The statistical analysis of compositional data (with discussion). Journal of the Royal Statistical Society B 44, 139-177.

Aitchison, J., 1986. The Statistical Analysis of Compositional Data. Monographs on Statistics and Applied Probability. Chapman \& Hall Ltd., London (UK). 416 pp.

Aitchison, J., Greenacre, M.J., 2000. Biplots of compositional data. Applied Statistics 51, 375-392.

Armienti, P., Tarquini, S., 2002. Power law olivine crystal size distributions in lithospheric mantle xenoliths. Lithos 65, 273-285.
Basu, A., 1976. Petrology of Holocene fluvial sand derived from plutonic source rocks: implications to paleoclimatic interpretation. Journal of Sedimentary Petrology 46, 694-709.

Basu, A., 2003. A perspective on quantitative provenance analysis. Memorie Descrittive Carta Geologica d'Italia 61, 11-22.

Baynes, F.J., Dearman, W.R., 1978. The relationship between the microfabric and the engineering properties of weathered granite. Bulletin of the International Association of Engineering Geology 18, 191-197.

Blatt, H., 1967. Provenance determination and recycling of sediments. Journal of Sedimentary Petrology 37, 1031-1044.

Boulton, G.S., 1978. Boulder shapes and grain-size distribution of debris as indicators of transport paths through a glacier and till genesis. Sedimentology 25, 773-799.

Brace, W.F., 1964. Brittle fracture of rocks. In: Rudd, W.R. (Ed.), States of Stress in the Earth's Crust. Elsevier, New York, pp. 111-178.

Caracciolo, L., Le Pera, E., Muto, F., Perri, F., 2011. Sandstone petrology and mudstone geochemistry of the Peruc-Korycany Formation (Bohemian Cretaceous Basin, Czech Republic). International Geology Review 53 (9), 1003-1031.

Caracciolo, L., von Eynatten, H., Tolosana-Delgado, R., Critelli, S., Manetti, P., Marchev P., 2012. Petrological, geochemical and satatistical analysis of Eocene-Oligocene sandstones of the W Thrace basin, Greece and Bulgaria. Journal of Sedimentary Research $82,482-498$

Chayes, F., 1960. On correlation between variables of constant sum. Journal of Geophysical Research 65, 4185-4193.

Davies, D.K., Ethridge, F.G., 1975. Sandstone composition and depositional environment. American Association of Petroleum Geologists Bullettin 59, 239-264.

Debon, F., Lemmet, M., 1999. Evolution of Mg-K ratios in the Late Variscan plutonic rocks from the External Crystalline Massifs of the Alps (France, Italy, Switzerland). Journal of Petrology 40, 1151-1185.

Dickinson, W.R., 1970. Interpreting detrital modes of greywacke and arkose. Journal of Sedimentary Petrology 40, 695-707.

Dickinson, W.R., 1985. Interpreting provenance from detrital modes of sandstones. In: Zuffa, G.G. (Ed.), Provenance of Arenites. Dordrecht D. Reidel, pp. 333-362.

Dickinson, W.R., Suczek, C.A., 1979. Plate tectonics and sandstone compositions. American Association of Petroleum Geologists Bullettin 63, 2164-2182.

Egozcue, J.J., Pawlowsky-Glahn, 2006. Simplicial geometry for compositional data. In: Buccianti, A., Mateu-Figueras, G., Pawlowsky-Glahn, V. (Eds.), Compositional Data Analysis in the Geosciences: From Theory to PracticeGeological Society, London, Special Publications 264, 145-159.

Erkan, Y., 1970. Ein versuch zur quantitative Erfassung der Festigkeitseigen-schaften und zur quantitative Charakterisierung der Granite. Neues Jahrbuch für Mineralogie Abhandlungen 113, 91-109.

Folk, R.L., 1968. Petrology of Sedimentary Rocks. Hemphill's Publishing Co., Austin, TX 184 pp.

Franzinelli, E., Potter, P.E., 1983. Petrology, chemistry and texture of modern river sand, Amazon river system. Journal of Geology 91, 23-39.

Garzanti, E., Critelli, S., Ingersoll, R.V., 1996. Paleogeographic and paleotectonic evolution of the Himalayan range as reflected by detrital modes of tertiary sandstones and modern sands (Indus transect, India and Pakistan). Geological Society of America Bullettin 108 (6), 631-642.

Garzanti, E., Andò, S., Vezzoli, G., 2009. Grain-size dependence of sediment composition and environmental bias in provenance studies. Earth and Planetary Science Letters 277, 422-432.

Girty, G.H., 1991. A note on the composition of plutoniclastic sand produced in different climatic belts. Journal of Sedimentary Petrology 61, 428-433.

Grantham, J.H., Velbel, M.A., 1988. The influence of climate and topography on rockfragment abundance in modern fluvial sands of the southern Blue Ridge mountains, North Carolina. Journal of Sedimentary Petrology 58, 219-227.

Harrell, J.L., Blatt, H., 1978. Polycrystallinity: effects on the durability of detrital quartz. Journal of Sedimentary Petrology 48, 25-30.

Heins, W.A., 1993. Source rock texture versus climate and topography as controls on the composition of modern, plutoniclastic sand. Geological Society of America, Special Publication 284, 135-146.

Heins, W.A., 1995. The use of mineral interfaces in sand-sized rock fragments to infer ancient climate. Geological Society of America Bulletin 107, 113-125.

Helmold, K.P. 1985. Provenance of feldspathic sandstones-the effect of diagenesis on provenance interpretations. In: Zuffa, G.G. (Ed.), Provenance of Arenites, 148. D. Reidel, NATO Advanced Study Institute, Dordrecht, Netherlands, pp. 139-164.

Higgins, M.D., 2000. Measurement of crystal size distributions. American Mineralogist $85,1105-1116$.

Higgins, M.D., 2006. Quantitative Textural Measurements in Igneous and Metamorphic Petrology. Cambridge University Press, Cambridge. 270.

Ibbeken, H., Schleyer, R., 1991. Source and Sediment. A Case Study of Provenance and Mass Balance at An Active Plate Margin (Calabria, Southern Italy). Springer-Verlag, Berlin. 283 pp.

Ingersoll, R.V., 1990. Actualistic sandstone petrofacies: discriminating modern and ancient source rocks. Geology 18, 733-736.

Ingersoll, R.V., Bullard, T.F., Ford, R.L., Grimm, J.P., Pickle, J.D., Sares, S.W., 1984. The ef fects of grain size on detrital modes: a test of the Gazzi-Dickinson point-counting method. Journal of Sedimentary Petrology 54 (1), 103-116.

Irfan, T.Y., Dearman, W.R., 1978. Engineering classification and index properties of weathered granite. International Association of Engineering Geology Geological Bullettin 17, 79-90.

James, W.C., Mack, G.H., Suttner, L.J., 1981. Relative alteration of microcline and sodic plagioclase in semi-arid and humid climates. Journal of Sedimentary Petrology 51, 151-164.

Johnsson, M.J., 1993. The system controlling the composition of clastic sediments. In Johnsson, M.J., Basu, A. (Eds.), Processes Controlling the Composition of Clastic SedimentsGeological Society of America, Special Paper 284, 1-19. 
Johnsson, M.J., Stallard, R.F., Lundberg, N., 1991. Controls on the composition of fluvia sands from a tropical weathering environment: sands of the Orinoco River drainage basin, Venezuela and Colombia. Journal of Geology 103, 1622-1647.

Kairo, S., Suttner, L.J., Dutta, P.K., 1993. Variability in sandstone composition as a function of depositional environment in coarse-grained delta system. In: Johnsson, M.J., Basu, A. (Eds.), Processes Controlling the Composition of Clastic Sediments. Geological Society of America, Special Paper 284, 263-283.

Labhart, T.P., 1977. Aarmassiv und Gottardmassiv. In: Gwinner, M.P. (Ed.), Sammlung geologischer Führer, Bd. 63. Gebrüder Bornträger, Berlin/Stuttgart, p. 173.

Le Pera, E., Arribas, J., Critelli, S., Tortosa, A., 2001. The effects of source rocks and chemical weathering on the petrogenesis of siliciclastic sand from the Neto River (Calabria, Italy): implications for provenance studies. Sedimentology 48, 357-378.

Lidstrom, L., 1968. Surface and bond-forming properties of quartz and silicate minerals and their application in mineral processing techniques. Acta Polytechnica Scandinavica Chemistry lncluding Metallurgy Series 75, 149.

Lorimer, G., 1976. The plastic deformation of minerals. In: Strens, R.G.J. (Ed.), The Physics and Chemistry of Minerals arid Rocks. Wiley, London, pp. 3-17.

Mack, G.H., Suttner, L.J., 1977. Paleoclimatic interpretation from a petrographic comparison of Holocene sands and the Fountain Formation (Pennsylvanian) in the Colorado Front Range. Journal of Sedimentary Petrology 47, 89-100.

McDonald, D.A., Surdam, R.C., 1984. Clastic diagenesis. American Association of Petroleum Geologists Memoir 37, 434.

McWilliams, R., 1966. The role of microstructure in the physical properties of rocks. pp. 175-189 In: the American Society for Testing Materials (Ed.), Testing Techniques for Rock Mechanics. A.S.T.M. Stand., 402, pp. 175-189.

Michalski, I., Soom, M., 1990. The Alpine thermo-tectonic evolution of the Aar and Gotthard massifs, Central Switzerland: fission track ages on zircon and apatite and $\mathrm{K} / \mathrm{Ar}$ mica ages. Schweizerische Mineralogische und Petrographische Mitteilungen 70, 373-387.

Moss, A.J., 1966. Origin, shaping and significance of quartz sand grains. Journal of the Geological Society of Australia 13, 97-136.

Moss, A.J., Green, P., 1975. Sand and silt grains: predetermination of their formation and properties by microfractures in quartz. Journal of the Geological Society of Australia 22, 485-495.

Osborne, R.H., Bomer, E.J., Wang, Y.C., Yi, Lu, 1993. Application of a tumbler experiment using granodioritic grus to examine the character of quartz-grain fracture in highgradient streams. In: Johnsson, M.J., Basu, A. (Eds.), Processes Controlling the Composition of Clastic SedimentsGeological Society of America, Special Paper 284 211-234.

Palomares, M., Arribas, J., 1993. Modern stream sands from compound crystalline sources: composition and sand generation index. In: Johnsson, M.J., Basu, A. (Eds.), Processes controlling the composition of clastic sedimentsGeological Society of America, Special Paper 284, 313-322.

Pettijohn, F.J., Potter, P.E., Siever, R., 1972. Sands and Sandstones. Springer-Verlag, New York, p. 618.

Pettijohn, F.J., 1975. Sedimentary Rocks, 3rd edition. Harper \& Row Publ, New York $628 \mathrm{pp}$.

Pirard, E., 2004. Multispectral imaging of ore minerals in optical microscopy. Mineralogical Magazine 68, 323-333.

Pittman, E.D., 1970. Plagioclase feldspar as an indicator of provenance in sedimentary rocks. Journal of Sedimentary Petrology 40, 591-598.

Riezebos, P.A., Van der Waals, L., 1974. Silt-sized quartz particles: a proposed source Sedimentary Geology 12, 279-285.

Schaltegger, U., 1990a. The Central Aar granite: highly differentiated calc-alkaline magmatism in the Aar Massif (Central Alps, Switzerland). European Journal of Mineralogy 2, 245-259.

Schaltegger, U., 1990b. Post-magmatic resetting of Rb-Sr whole rock ages-a study in the Central Aar Granite (Central Alps, Switzerland). Geologische Rundschau 79 (3), 709-724.

Schaltegger, U., Corfu, F. 1994. The age and source of late Hercynian magmatism in the Central Alps: evidences from precise U-Pb ages and initial $\mathrm{Hf}$ isotopes. Contributes to Mineralogy and Petrology 111, 329-344.

Scholle, P.A., Schluger, P.R., 1979. Aspects of diagenesis. Society of Economic Paleontologists and Mineralogists, Special Publication $26443 \mathrm{pp}$.

Simmons, G., Richter, D., 1976. Microcracks in rocks. In: Strens, R.G.J. (Ed.), The Physics and Chemistry of Minerals and Rocks. Wiley, London, pp. 105-137.
Slatt, R.M., Eyles, N., 1981. Petrology of glacial sand: implications for the origin and mechanical durability of lithic fragments. Sedimentology 28, 171-183.

Smalley, I.J., Vita-Finzi, C., 1968. The formation of fine particles in sandy deserts and the nature of "desert" loess. Journal of Sedimentary Research 38 (3), 766-774.

Sprunt, E.S., Nur, A., 1979. Microcracking and healing in granites new evidence from cathodoluminescence. Science 205, 495-497.

Streckeisen, A., 1976. To each plutonic rock its proper name. Earth-Science Reviews 12 (1), 1-33.

Suttner, L.J., 1974. Sedimentary petrographic provinces: an evaluation. In: Ross, C.A. (Ed.), Paleogeographic and Provinces and ProvincialitySociety of Economic Paleontologists and Mineralogists, Special Publication 21, 75-84

Suttner, L.J., Dutta, P.K., 1986. Alluvial sand composition and paleoclimate, I. Framework mineralogy. Journal of Sedimentary Petrology 56, 329-345.

Suttner, L.J., Basu, A., Mack, G.H., 1981. Climate and the origin of quartz arenites. Journal of Sedimentary Petrology 51, 1235-1246.

Tarquini, S., Favalli, M., 2010. A microscopic information system (MIS) for petrographic analysis. Computers and Geosciences 36, 665-674.

Terribile, F., FitzPatrick, E.A., 1992. The application of multilayer digital image processing techniques to the description of soil thin sections. Geoderma 55, 159-174.

Todd, T.W., 1968. Paleoclimatology and the relative stability of feldspar minerals under atmospheric conditions. Journal of Sedimentary Petrology 38, 832-844.

Tolosana-Delgado, R., 2012. Uses and misuses of statistics in sedimentology: extracting what we can from compositional data sets. Sedimentary Geology 280, 60-79.

Tortosa, A., Palomares, M., Arribas, J., 1991. Quartz grain types in Holocene deposits from the the Spanish Central System: some problems in provenance analysis. In: Morton, A.C., Todd, S.P., Haughton, P.D.W. (Eds.), Developments in Sedimentary Provenance StudiesGeological Society of London, Special Publication 57, 47-54.

Valloni, R., 1985. Reading provenance from modern marine sands. In: Zuffa, G.G. (Ed.), Provenance of Arenites, 148. D. Reidel, NATO Advanced Study Institute, Dordrecht, Netherlands, pp. 309-332.

van de Kamp, P.C., Helmold, K.P., Leake, B.E., 1994. Holocene, Paleogene and Permian arkoses of the Massif Central, France: mineralogy, chemistry, provenance, and hydrothermal alteration of the type arkose. Journal of Sedimentary Research A64, 17-33.

von Eynatten, H., Tolosana-Delgado, R., Karius, V., 2012. Sediment generation in modern glacial settings: Grain-size and source-rock control on sediment composition. Sedimentary Geology 280, 80-92.

Walker, P.H., Hutka, J., 1971. Use of the Coulter counter (Model B) for particle-size analysis of soils. Div. Soils Tech. Paper No. 1. Melbourne, Australia: CSIRO.

Weltje, G.J., 2002. Quantitative analysis of detrital modes: statistically rigorous confidence regions in ternary diagrams and their use in sedimentary petrology. EarthScience Reviews 57, 211-253.

Weltje, G.J., 2004. A quantitative approach to capturing the compositional variability of modern sands. Sedimentary Geology 171, 59-68.

Weltje, G.J., 2012. Quantitative models of sediment generation and provenance: State of the art and future developments. Sedimentary Geology 280, 4-20.

Weltje, G.J., von Eynatten, H., 2004. Quantitative provenance analysis of sediments: review and outlook. Sedimentary Geology 171 (1-4), 1-11.

Weltje, G.J., Meijer, X.D., de Boer, P.L., 1998. Stratigraphic inversion of siliciclastic basin fills: a note on the distinction between supply signals resulting from tectonic and climatic forcing. Basin Research 10, 129-153.

White, S., 1976. The role of dislocation processes during tectonic deformations, with particular reference to quartz. In: Strens, R.G.J. (Ed.), The Physics and Chemistry of Minerals and Rocks. Wiley, London, pp. 75-91.

Whitmore, G.P., Crook, K.A.W., Johnson, D.P., 2004. Grain size control of mineralogy and geochemistry in modern river sediment, New Guinea collision, Papua New Guinea. Sedimentary Geology 171, 129-157.

Young, S.W., Basu, A., Mack, G.H., Darnell, N., Suttner, L.J., 1975. Use of size-composition trends in Holocene soil and fluvial sand for paleoclimate interpretation. Proceeding IX Int. Congr. of Sedimentology, Th. 1, Nice, France, pp. 28-36.

Zuffa, G.G., 1985. Optical analyses of arenites: influence of methodology on compositional results. In: Zuffa, G.G. (Ed.), Provenance of Arenites, 148. D. Reidel, NATO Advanced Study Institute, Dordrecht, Netherlands, pp. 165-189.

Zuffa, G.G., 1987. Unravelling hinterland and offshore palaeogeography from deepwater arenites. In: Leggett, J.K., Zuffa, G.G. (Eds.), Marine Clastic Sedimentology. Concepts and Case Studies. Graham and Trotman, London, pp. 39-61. 